\title{
Alpha-lipoic acid as a pleiotropic compound with potential therapeutic use in diabetes and other chronic diseases
}

\author{
Marilia Brito Gomes ${ }^{1 *}$ and Carlos Antonio Negrato ${ }^{2}$
}

\begin{abstract}
Alpha-lipoic acid is a naturally occurring substance, essential for the function of different enzymes that take part in mitochondria's oxidative metabolism. It is believed that alpha-lipoic acid or its reduced form, dihydrolipoic acid have many biochemical functions acting as biological antioxidants, as metal chelators, reducers of the oxidized forms of other antioxidant agents such as vitamin $C$ and $E$, and modulator of the signaling transduction of several pathways. These above-mentioned actions have been shown in experimental studies emphasizing the use of alpha-lipoic acid as a potential therapeutic agent for many chronic diseases with great epidemiological as well economic and social impact such as brain diseases and cognitive dysfunctions like Alzheimer disease, obesity, nonalcoholic fatty liver disease, burning mouth syndrome, cardiovascular disease, hypertension, some types of cancer, glaucoma and osteoporosis. Many conflicting data have been found concerning the clinical use of alpha-lipoic acid in the treatment of diabetes and of diabetes-related chronic complications such as retinopathy, nephropathy, neuropathy, wound healing and diabetic cardiovascular autonomic neuropathy. The most frequent clinical condition in which alpha-lipoic acid has been studied was in the management of diabetic peripheral neuropathy in patients with type 1 as well type 2 diabetes. Considering that oxidative stress, a imbalance between pro and antioxidants with excessive production of reactive oxygen species, is a factor in the development of many diseases and that alpha-lipoic acid, a natural thiol antioxidant, has been shown to have beneficial effects on oxidative stress parameters in various tissues we wrote this article in order to make an up-to-date review of current thinking regarding alpha-lipoic acid and its use as an antioxidant drug therapy for a myriad of diseases that could have potential benefits from its use.
\end{abstract}

Keywords: Alpha-lipoic acid, Biochemical action, Diabetes mellitus, Chronic diseases

\section{Introduction}

Alpha-lipoic acid (ALA) also known as thioctic acid (TA) and 1,2 dithiolane -3-pentanoic acid, is a naturally occurring substance, that is essential for the function of different enzymes of oxidative metabolism [1-3]. ALA was discovered in 1937 by Snell [4] but only in 1951 it was isolated by Reed [5]. The first clinical use of ALA has been described in Germany in 1959 for the treatment of acute poisoning with amanita phalloides commonly known as death cap [from mushrooms] a deadly poison widely distributed in Europe Moreover, soon after, the

\footnotetext{
*Correspondence: mariliabgomes@gmail.com

'Department of Internal Medicine, Diabetes Unit, State University Hospital of Rio de Janeiro, Avenida 28 de Setembro, 77, $3^{\circ}$ andar CEP 20.551-030, Rio de Janeiro, Brazil

Full list of author information is available at the end of the article
}

same authors described its utility in treating neuropathic complaints [6]. Nowadays it is believed that ALA or its reduced form, dihydrolipoic acid (DHLA) have many biochemical functions acting as biological antioxidants, as metal chelators, reducing the oxidized forms of other antioxidant agents such as vitamin $\mathrm{C}$ and $\mathrm{E}$ and glutathione (GSH), and modulating the signaling transduction of several pathways, like insulin and nuclear factor kappa B (NFkB) [1]. ALA has also shown to improve endothelial dysfunction [7] and to reduce oxidative stress post exercise training [8]; it also protects against the development of atherosclerosis and inhibits the progression of an already established atherosclerosis plaque $[9,10]$. These above-mentioned actions have emphasized the use of ALA as a potential therapeutic agent for many chronic diseases with great epidemiological as well economic and 
social impact such as diabetes mellitus (DM) and its complications [11,12], hypertension [13], Alzheimer's disease (AD) [14], Down syndrome [15], cognitive dysfunction and some types of cancer [16]. Currently the use of ALA as a dietary supplement is growing in many aspects of medical and nutritional management of patients.

Considering the pleiotropic actions of ALA or DHLA in so many different organs and systems, in many different ways, this review has the objective to improve the clinical and biochemical understanding of its potential use in routine clinical care for a large spectrum of pathologies.

\section{Synthesis, biochemical properties, absorption and bioavailability}

ALA is commonly found in dietary components such as vegetables (spinach, broccoli, tomato) and meats, mainly viscera and also in many dietary supplements. ALA can be also synthesized through enzymatic reactions in plants and animals' mitochondria from octanoic acid and cysteine (as a sulfur donor) $[17,18]$. As a sulfur containing substance, ALA is considered a thiol compound. Mammalian cells can synthesize ALA through the action of mitochondria lipoic acid synthase (LASY) which can be down-regulated in different clinical conditions [18].

ALA exists in two enantiomeric (optical isomers) forms, $\mathrm{R}$ and $\mathrm{S}$, (Figure 1) being the $\mathrm{R}$ isoform an essential cofactor for mitochondrial enzymes of oxidative metabolism since it is joined in amide linkage to $€$-amino group of lysine residues (lipoamide) [17]. The following enzymes use R-ALA as a cofactor: pyruvate dehydrogenase (PDH),

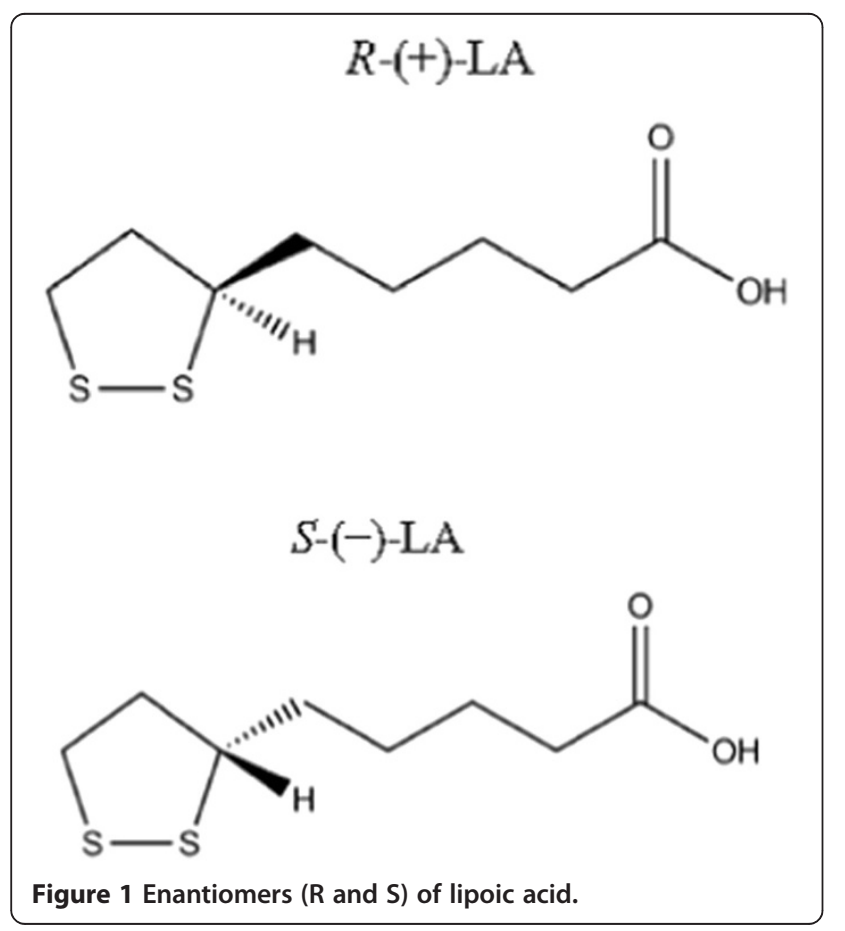

branched chain $\alpha$-keto-acid dehydrogenase (KDH) and $\alpha$-ketoglutarate dehydrogenase (KGDH) $[18,19]$. Pyruvate dehydrogenase is a multienzyme complex, composed by three enzymes, which catalyze in three steps the irreversible oxidative decarboxylation of pyruvate into acetyl coenzyme A (acetyl-CoA), which is a component of the citric acid cycle [19]. The other above-mentioned enzymes also catalyze the oxidative decarboxylation of other $\alpha$-keto-acid such as $\alpha$-ketoglutarate, valine, leucine, isoleucine. R-ALA is also a cofactor of glycine cleavage system which degrades glycine into pyruvate [20].

The absorption and bioavailability of ALA have been studied mainly from dietary supplements where ALA exists as an admixture of R-ALA and S-ALA. In general, the absolute bioavailability of both ennatiomers is not greater than $40 \%$ which decreases with food intake [12]. Therefore, ALA must be taken 30 min before meals. Some experimental studies have shown that R-ALA has greater biopotency in several metabolic pathways compared to S-ALA [21].

After oral intake, ALA is absorbed by the gastrointestinal tract and is transported to different organs such as brain because it has the potential of freely cross the blood-brain barrier [3]. Independently of the original sources (diet or nutritional supplements) ALA is reduced to DHLA and metabolized in the liver in different metabolites like bisnorlipoate and, tetranorlipoate, and has renal excretion.

So far, some systems have been associated with the cellular transport of ALA like sodium dependent transport, a transmembrane protein which is produced by the SLC5A6 gene that also translocates other vitamins and cofactors. Both transporters are also responsible for ALA intestinal uptake [22].

\section{Antioxidant properties}

ALA and its reduced form DHLA, are considered powerful natural antioxidant agents with a scavenging capacity for many reactive oxygen species $[23,24]$. The chemical structure of both compounds is showed in Figure 2. It is important to note that there is no agreement about the specific scavenging capacity of each form [23-31]. Although it is beyond of the scope of this review, for instances it was described a different scavenging ability of ALA and DHLA on aqueous and membrane phase of an experimental study which means that the environment could be an important factor for determining its scavenging capacity (24). A summary of these data are presented in Table 1. ALA/DHLA have some important advantages over other antioxidant agents such as vitamin $\mathrm{E}$ and $\mathrm{C}$, because they have amphiphilic properties that confer their antioxidant actions in the membrane as well as in the cytosol [23].

ALA/DHLA can also regenerate other antioxidant substances such as vitamin $C$, vitamin $E$ and the ratio of 


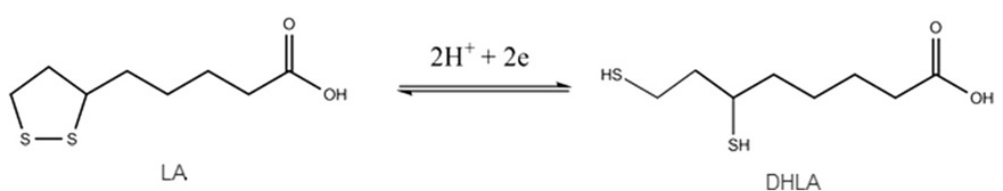

Figure 2 Chemical structure of alpha lipoic acid (ALA) and its reduced from dihydrolipoic acid (DHLA).

reduced/oxidized glutathione (GSH/GSSG) [17]. Glutathione is a sulfur tripeptide containing glutamate, cysteine and glycine [32]. Their biosynthesis depend on substrate availability (cysteine), which is enhanced by ALA/DHLA which convert cystine into cysteine and also through gene expression [12]. Considering the latter action, ALA/ DHLA is an activator/inducer of translocation of nuclear factor erythroid 2-related factor (Nrf2) to the nucleus for regulation of antioxidant gene expression [33]. GSH which has also a connection with circadian rythms, has many functions over different intracellular processes like ageing, oxidative balance and detoxification of many pollutants [34].

A pro-oxidant effect of ALA is also described in experimental studies, but it is generally observed at higher concentrations than the usual plasmatic concentration observed after oral or intravenous infusion of ALA found

Table 1 Antioxidant action of ALA and DHLA upon reactive oxygen species and references

\begin{tabular}{|c|c|c|}
\hline Reactive oxygen species & ALA & DHLA \\
\hline Hydrogen peroxide & Yes (12) & Yes (12) \\
\hline$\left(\mathrm{H}_{2} \mathrm{O}_{2}\right)$ & No (23) & No (23) \\
\hline \multicolumn{3}{|l|}{ Superoxide } \\
\hline \multirow[t]{2}{*}{$\left(\mathrm{O}_{2}^{-}\right)$} & No (23) & Yes $(12,27,28)$ \\
\hline & & No (23) \\
\hline \multicolumn{3}{|l|}{ Hydroxyl radical } \\
\hline \multirow[t]{2}{*}{$\left(\mathrm{HO}^{-}\right)$} & Yes & Yes \\
\hline & $(23,24,27)$ & (27) \\
\hline SInglet oxygen & Yes $(12,29)$ & Yes (29) \\
\hline$\left(\mathrm{O}_{2}{ }^{*}\right)$ & & No (24) \\
\hline Peroxynitrite & Yes $(12,25)$ & Yes $12,(25)$ \\
\hline \multicolumn{3}{|l|}{$\left(\mathrm{ONOO}^{-}\right)$} \\
\hline Nitric oxide radical & Yes & Yes (12) \\
\hline (NO) & $(12,26)$ & No (26) \\
\hline Hypochlous acid & Yes $(23,24,31)$ & Yes (31) \\
\hline \multicolumn{3}{|l|}{$(\mathrm{HOCL})$} \\
\hline Peroxyl radical & Yes (23) & Yes $(23,30)$ \\
\hline$\left(\mathrm{HO}_{2 . .}\right)$ & No (30) & \\
\hline
\end{tabular}

in human studies $[35,36]$. So far, the pro-oxidant action of ALA/DHLA is not fully understood but could be related to different direct or indirect reactions [37] such as oxidation of DHLA by ubisemiquinone [36], to the maintenance of NrF2 into the cytosol through a linkage to Keap 1 protein, resulting in the inhibition of the transcription of cytoprotective genes which include many antioxidant genes $[38,39]$ or to an ubiquination of Nrf2 in a Keap1-dependent action [38].

\section{Metal chelator properties}

Chelation is a powerful function for most living species. A chelator compound has an important function in most systems because it can counteract agents which have a potential oxidant action. Although chelation therapy plays a prominent role in the clinical treatment of metal intoxication, its use in the treatment of some diseases such as DM, cardiovascular and neurodegenerative entities albeit controversial have been subject to an extensive discussion [40].

ALA/DHLA are considered as chelator compounds because they are able to chelate divalent transient metal ions both in vivo and in vitro but by different mechanisms of action [41-43]. LA chelates mostly the $\mathrm{Mn}^{2+}, \mathrm{Cu}^{2+}$, $\mathrm{Pb}^{2+}$ and $\mathrm{Zn}^{2+}$. In addition to the previously mentioned ions, DHLA is also able to chelate $\mathrm{Hg}^{2+}$ and $\mathrm{Fe}^{3+}$. Both iron and cupper are recognized as mediators for the production of reactive oxygen species. Moreover, the actions of ALA/DHLA as chelating compounds do not cause metal depletion.

\section{Action upon transduction signaling systems Insulin pathway}

ALA has many actions in the insulin metabolic pathways, glucose uptake and glycogen synthesis with some differences between both isomers. In vitro studies have shown that R-ALA increases the translocation of GLUT1 and GLUT4 to the plasmatic membrane of adipocytes [21,41-43] and skeletal muscle cells kept in a culture milieu [42]. Moreover, these events are associated with enhanced activity of proteins of the insulin signaling pathway like insulin receptor (IR), insulin receptor substrate 1 (IRS1), Phosphatidylinositide 3-kinase (PI3K) and 
protein kinase B (AKT) [42]. These events were also observed when Zucker rats, that are animal models of insulin resistance, were studied [43]. There is still a controversy if this action of ALA is totally insulindependent or not [41-43]. Furthermore, in an animal model of isolated rat muscles ALA inhibited glycogen synthesis, and action which is considered to have a pro-oxidant effect [32]. In general the S-ALA did not show a significant effect upon glucose disposal [41-43].

\section{Nuclear factor kappa B}

Nuclear factor kappa B (NFkB) is a transcription factor which is maintained in an inactive form in the cytosol because of its capacity in binding to an inhibitor kinase of NFkB activity, IKK [44]. Oxidative-stress is associated with hyperglycemia [45-48], and the existence of other conditions like viruses, some pathogens, and radiation are supposed to phosphorylate $\mathrm{IkB}$ resulting in its degradation, liberation and activation of $\mathrm{NFkB}$ which translocates to the nucleus to induce the transcription of several molecules related to inflammation, vascular adhesion and migration of monocytes [44]. ALA inhibits NFkB probably because of its action on the inhibition of the degradation of IkB through modulation of upstream kinases like MAPK [12] or its ability to regenerate vitamin E resulting in inhibition of protein kinase $C$ which is also able to phosphorylate IkB [49]. This action of ALA seems to be independent of its antioxidant action [50]. Several experimental studies in vitro [50] and in vivo in rats [51] have shown the anti-inflammatory actions of ALA but few studies have addressed this subject in humans [52].

\section{Adenosine monophosfatase protein kinase}

ALA has some important functions in the activity and expression of $5^{\prime}$ adenosine monophosphate-activated protein kinase (AMPK) in peripheral tissues and in brain (hypothalamus). AMPK is considered a multifunctional protein involved in many intracellular pathways related to metabolism, stress response, cell cycle and ageing [53]. Currently, AMPK plays an important role in linking nutritional factors and cancer and is considered to be a promising therapeutic target for cancer prevention and treatment [54].

AMPK is a cellular energy sensor and it is activated by liver kinase B1 (LKB-1) and $\mathrm{Ca} /$ calmodulin dependent protein kinase (CaMKK). Activation of AMPK results in down regulation of transcriptional events that promote synthesis of gluconeogenic enzymes, synthesis of fatty acids and up regulation of metabolic pathways resulting in an increased ATP production through glucose and fatty acids oxidation [54]. Moreover, AMPK can induce trasnlocation of GLUT4 to plasma membrane independent of insulin action [54].
So far, it is still unknown which is the mechanism that induces activation of AMPK by ALA in peripheral tissues. According to one study with myoblast cells culture, ALA could increase the activation of AMPK indirectly by activating CaMKK which becomes activated by an increase in intracellular $\mathrm{Ca}^{2+}[55]$. The inhibition of CaMKK abolishes this action [55]. Indeed, these actions of ALA-AMPK could also increase energy expenditure by increasing the activity of protein kinase-peroxisome proliferatoractivated receptor-gamma coactivator-1alpha (PGC1-alpha) signaling pathway which is responsible for mitochondrial biogenesis [56]. All the above-mentioned actions resulting from ALA activating AMPK will cause a decrease in plasma glucose, an increase in insulin sensitivity and probably weight loss [53]. Recently it was described an action of ALA upon AMPKK in insulinoma cells culture and isolated islets of Langerhans which resulted in a decreased insulin secretion by 25 to $30 \%$ at low $(2.8 \mathrm{mmol} / \mathrm{L})$ and high $(15 \mathrm{mmmol} / \mathrm{L})$ glucose concentrations [57]. This event was observed both with acute and chronic treatment with ALA. Considering this latter action, another study showed a protective effect of ALA upon 2-deoxy-D-ribose induced oxidative damage and insulin expression in cultured cells and rat islets [58]. This protective action seems to be related to an increased intracellular GSH concentration. Both studies have brought to light important informations about the multiple effects of ALA upon beta cells. The study design, the stimulus and the concentration of ALA used in the experiments could have accounted for the different results that have been found [58].

ALA is also able to modulate the activity of AMPK in the brain by metabolic stresses that inhibit ATP production such as ischemia, hypoxia, glucose deprivation as well as by oxidative stress [59]. Recent studies of experimental neuronal models are pointing to AMPK's possible roles beyond energy sensing, some reporting brain protective effects [60], while others reporting detrimental effects [61]. These discrepancies may be related to the dose of glucose added in the culture medium.

It has also been found that hypothalamic AMPK is important in the central regulation of appetite and energy expenditure and that ALA exerts anti-obesity effects by suppressing hypothalamic AMPK activity [62]. In this setting, ALA has an anorexic property and should be a potential anti-obesity drug [63].

\section{Relationship between the dose of ALA and its effects in experimental studies}

In most experimental studies performed in vitro a wide range of ALA doses and glucose concentrations were used, from $10 \mathrm{umol} / \mathrm{L}$ to 5 and from $2.0 \mathrm{mmol} / \mathrm{L}$ to $15 \mathrm{mmol} / \mathrm{L}$, respectively and a clear dose-dependent response was observed $[14,16,58-61,64-66]$. The majority 
of these studies did not give an information about which type of ALA was used: if a racemic admixture of R-ALA and S-ALA, only R-ALA or only S-ALA. In one study a hormonal admixture of ALA was used [65]. The same was noted in animal studies with different purposes $[10,56,63,64,67-72]$ when the doses used were described as percentage [63] to doses described as $\mathrm{mg} / \mathrm{rat}$ [68] or described as $\mathrm{mg} / \mathrm{kg}$ which ranged from 20 to $100 \mathrm{mg} / \mathrm{kg}[10,69,70,72]$. As observed in in vitro studies, most of the in vivo studies did not give an information about which type of ALA was used. The above-mentioned events could have resulted in protective or deleterious actions of ALA upon different cells as recently pointed out [59]. All these informations must be considered in relation to the absorption rate of the usual prescribed dose of $600 \mathrm{mg}$ which reachs a plasmatic peak of $4 \mathrm{ug} / \mathrm{ml}$, that corresponds to a plasmatic concentration of 0.0194 $\mathrm{mmol} / \mathrm{L}$, in about 30 minutes after its ingestion.

\section{Clinical use of ALA in conditions other than diabetes Brain diseases and cognitive dysfunction}

Brain is considered to be one of the major glucose and oxygen consumer organs, although it corresponds to only $2 \%$ of the total body weight [73]. Neurons and astrocytes are the most active cells of neurometabolism and are considered to be the neurometabolic couple. Currently, oxidative stress, an imbalance between the production of ROS and the antioxidant defenses plays an important function in the occurrence of neurodegenerative diseases as well in brain injuries, mediated mainly by mitochondrial dysfunction $[14,64,74]$. Moreover, the brain has a great sensitivity to oxidative stress-induced damage [75]. Considering ALA as an antioxidant compound its use has been reported in some brain diseases and associated with cognitive dysfunction such as Down syndrome [15] and AD [76,77].

In a randomized, double blind placebo- controlled study in patients with Down Syndrome with pre-dementia, the use of 900 UI of alpha-tocopherol plus $200 \mathrm{mg}$ of ascorbic acid and $600 \mathrm{mg}$ of ALA for two years did not show improvement in cognitive dysfunction or stabilization of cognitive decline [15]. It is well known that these patients are at an increase risk in developing $\mathrm{AD}$, and oxidative stress is considered to be an important feature of the Down syndrome.

In $\mathrm{AD}, \mathrm{ALA}$ in association with $\mathrm{n}$-acetylcysteine has shown to have a protective effect upon oxidative stress in fibroblasts decreasing caspase proteins which were responsible for apoptotic processes in patients with $\mathrm{AD}$ [14]. In a triple transgenic animal model of AD, ALA was able to improve neurons plasticity and improve many pathways of insulin signaling in the brain similar to the action described with metformin $[77,78]$. So far, only two clinical studies have addressed the use of ALA (600 mg/daily) in patients with $\mathrm{AD}$, both studies were open-labeled $[79,80]$. One study was conducted with nine patients followed by 12 months [79] and the other with 43 patients followed by 24 months [68], both showing a slowing in the disease progression. Meanwhile, when ALA was associated with exercise training in animal model an increase in some antioxidant enzymes were observed [81].

\section{Obesity}

The increasing prevalence of obesity worldwide is an important epidemiological issue because it is occurring in parallel with the increase in the prevalence of DM and cardiovascular disease (CVD). Moreover, it is well known that both conditions are associated with insulin resistance, an increased plasmatic level of free fatty acids, of proinflammatory cytokines such as tumor necrosis factor alfa (TNF- $\alpha$ ), interleukin 6 (IL-6) and decreased levels of adiponectin which is considered to be a protective cytokine $[65,82,83]$. The above-mentioned mechanisms seem to be related to oxidative stress and activation of NfKB [84]. ALA has many actions that may result in weight loss such as activation of AMPK in peripheral and brain tissue [59], inhibition of NfKB [44] and adipocyte differentiation [65]. Animal studies showed that rats fed with a high fat diet with ALA supplementation had less weight gain and better plasmatic lipid profile than the control group [65]. Some of these effects, such as the increase in HDL-cholesterol and the decrease in LDLcholesterol levels were dose dependent. Some studies suggest that the ability of ALA supplementation in preventing insulin resistance might be related in part to the stimulation of AMPK and adiponectin in white adipose tissue [82] and attenuation of monocyte chemokine protein 1 (MCP-1) and TNF- $\alpha$ [71]. The authors suggested that ALA may modulate visceral adipose inflammation.

Data from human studies have shown conflicting results related to lipid metabolism [8,85-88]. Considering weight loss, the studies have used doses of ALA ranging from $1,000 \mathrm{mg}$ to $1,800 \mathrm{mg}$ for up 20 weeks in obese patients with or without glucose intolerance and have shown a weight loss around $3 \mathrm{~kg}[8,87,88]$, that corresponds to a $3 \%$ of weight loss [87]. It is important to emphasize that the use of sibutramine for one year at a constant dose of $15 \mathrm{mg} /$ daily resulted in a weight loss of about 7\% [89]. However, in obese glucose intolerant subjects ALA has only shown an increase in LDL-oxidation in comparison to subjects who completed 12 weeks of ALA used associated with exercise [8]. Another study did not show any advantage of ALA supplementation for two weeks over lipidinduced insulin resistance in obese or overweight subjects [85]. However, an intravenous treatment with $600 \mathrm{mg}$ of ALA for two weeks in obese patients with glucose intolerance resulted in improvement of insulin resistance, decreased levels of free fatty acids, LDL-cholesterol as well oxidized LDL, TNF $\alpha$ and IL-6 [86]. 
The use of $1,200 \mathrm{mg} / \mathrm{d}$ of ALA for 10 weeks in an open-label pilot trial in patients with schizophrenia without DM taking atypical antipsychotic drugs showed a weight loss of $-2.2 \mathrm{~kg} \pm 2.5 \mathrm{~kg}$. The weight loss was greater in patients taking antihistaminic antipsychotic agents, mainly clozapine, olanzapine or quetiapine [88].

Further studies are necessary to address the clinical use of ALA as anti-obesity drug with more complete data about dietary habits including the ingestion of fruits and vegetables which are the main source of antioxidants in a regular diet.

\section{Nonalcoholic fatty liver disease}

Non-alcoholic fatty liver disease (NAFLD) is considered the most prevalent liver disease worldwide. NAFLD is frequently associated with metabolic syndrome, obesity, DM and dyslipidemia [90]. During the natural history of NAFLD up to $25 \%$ of the patients developed non-alcoholic steatohepatites (NASH) [91]. Currently, mitochondria dysfunction, oxidative stress and inflammation play a key role in the pathogenesis of NAFLD and NASH [55]. Some animal studies have brought to light the possible mechanisms involved in the action of ALA in NAFLD and NASH in the last years [92,93]. In one study, the use of ALA was followed by improvement in serum levels of insulin, free fatty acids, glucose, IL-6, triglycerides and markers of inflammation and of innate immune activation (Toll-like receptor 4, TLR4) in liver biopsy [93]. Two other studies using animals fed with a high fat diet showed that ALA induced an increase in uncoupling protein 2 which inhibits electron transport chain resulting in decreased ATP and lipid synthesis [92]. Moreover this action on mitochondria efficiency seems to be related to an increased action of the sirtuin proteins [94]. These proteins have many actions in several intracellular pathways associated with antioxidant defense $[95,96]$.

\section{Burning mouth syndrome}

Burning mouth syndrome (BMS) is a chronic disease characterized by pain, burning and itching of the oral cavity without association to any systemic disease. Sometimes xerostomia and dysgeusia could be present [97]. BMS is more prevalent in women in the menopause period. In Brazil its prevalence is of 1\% [98]. The etiology is probably multifatorial including psychiatric diseases and hypothyroidism [99]. ALA was used during two months in patients with BMS in a dose of $600 \mathrm{mg}$ daily but with conflicting results [98-100].

\section{Cardiovascular disease and endothelial function}

The main cause of mortality in non diabetic as well as in diabetic subjects worldwide is CVD [101]. CVD is multifactorial being the oxidative stress and a proinflammatory state considered to be the most important mechanisms involved in the large spectrum of CVD [102]. In this setting, ALA which has antioxidant as well anti-inflammatory actions has been used in several studies, both animal [8-10,68-70] and human [9,103] addressing different aspects of CVD.

For instance, the acute use of ALA in a $600 \mathrm{mg}$ dose, associated with $1,000 \mathrm{mg}$ of vitamin $\mathrm{C}$ and $600 \mathrm{IU}$ of Vitamin $\mathrm{E}$ was able to ameliorate markers of oxidative stress and endothelial dysfunction evaluated by flowmediated vasodilation (FMD) of the brachial artery in the elderly [7]. The effects of ALA upon endothelial function and markers of oxidative stress were age dependent and it was not observed in young subjects. In contrast, a review of many clinical trials using chronic antioxidant therapy was not able to demonstrate benefits on CVD [103].

In animal models, those fed with a high cholesterol diet, the use of ALA for 12 weeks reduced oxidative stress and weight and improved vascular reactivity [10]. Moreover, a reduction in the wall volume of abdominal aorta with slowing rate of the plaque progression and a reduction of the expression of adhesion molecules in thoracic aorta were also observed. One important finding in this study was the demonstration that ALA decreased the activation of NfKB which regulates the expression of pro-inflammatory genes as well adhesion molecules [10].

The effects and mechanisms of ALA on myocardial infarct size and diabetic cardiomyopathy which is defined as a ventricular dysfunction in diabetic patients without any other cause, were also evaluated in animal studies $[66,67]$. Cardiac fibrosis which is the main feature of cardiomyopathy, was investigated in animal with streptozotocin (STZ) DM-induced [66]. In these animals the use of ALA had different actions such as improvement of cardiac function and cardiac fibrosis. Analyzing the left ventricular sections of these animals it was observed a better oxidative stress profile and a decreased expression of transforming growth factor $\beta$ and smooth muscle actin, both associated with collagen production.

In animal models of ischemia-reperfusion it was demonstrated that ALA ameliorates cardiac dysfunction with a decrease in the infarct size, TNF- $\alpha$, mieloperoxidase, markers of cell death (lactate dehydrogenase and creatinine kinase), and upregulates gene expression of several antioxidant enzymes [67]. The mechanisms of action of ALA were related to the phosphorylation of PI3K/AKT without any effect on nitric oxide production. Additionally, all these actions were dose dependent, being the dose of $15 \mathrm{mg} / \mathrm{kg}$ the most effective. No effects with lower or higher doses were observed [67].

A benefit obtained with the use of ALA in hypertension was described and could be related to oxidative stress as well as to the modulation of intracellular $\mathrm{Ca}^{2+}$ [3]. In animal studies of glucocorticoid-induced hypertension, the use of ALA prevented only dexamethasone 
induced-hypertension [65]. In human studies the use of ALA as a hypotensive agent presented conflicting results showing improvement or no effect [52,104]. For instance, the Island Study which used ALA $(300 \mathrm{mg} /$ d) plus irbesartan $(150 \mathrm{mg} / \mathrm{d})$ for 4 weeks in subjects with metabolic syndrome did not find any difference in blood pressure albeit an improvement in flow mediated vasodilation and a reduction in plasma levels of IL-6 and 8isoprostane [52]. Moreover it was also demonstrated that both drugs had a synergistic effect upon markers of endothelial dysfunction, inflammation and oxidative stress. It is important to emphasize that this study was not designed to evaluate blood pressure and the dose used of ALA was lower than the doses that are usually employed.

\section{Cancer}

Oxidative stress plays an important role in tumorigenesis [105]. ALA has been used as an anticancer agent mainly in experimental studies of different tumorigenesis cells type with promising results [16,106-110]. So far the exact molecular mechanisms involved in this action are unknown. Besides its antioxidant acitivity, another possibility could be its relation to the capacity of inducing cellular apoptosis as recently demonstrated in lung cells [106]. This effects may result from activation of caspases proteins induced by endoplasmic reticulum stress [109]. Another hypothesis is associated with the metabolism of cancer cells which convert preferentially glucose to lactate, a mechanism known as the Warburg effect [108]. ALA is the cofactor of pyruvate deydrogenase which converts pyruvate to acetil CoA resulting in a decrease in the formation of lactate [107]. The net effect of this action is the inhibition of glycolysis. Additionally, an inhibition of mTOR (target of rapamycina), a signaling pathway responsible for cell growth and related to insulin receptor phosphorylation- PI3K-AKT activation, has been demonstrated in assays using insulinoma cells [57]. This action resulted in an inhibition of insulin secretion and of beta cells growth [57]. In contrast, recent data have demonstrated an antiapoptotic action of ALA due to a activation of PI3-K/AKT [111]. In addition, in this study it was also showed a direct binding site of ALA to insulin receptor [111]. It is possible to speculate that ALA can act in alternative routes resulting in different effects. The few studies in humans are case reports [111]. In these studies ALA was used associated with other antioxidant agents [111] or with other anticancer drugs [111].

\section{Miscelaneous disorders}

ALA has been used in other clinical conditions such as glaucoma [72] and osteoporosis [112,113]. Both conditions are associated with an imbalance in the redox state. In a mouse model of glaucoma the increase in intraocular pressure was correlated to increased levels of lipid peroxidation and of oxidative stress-related genes expression in retina. Moreover, in these animals the addition of ALA to the diet enhanced antioxidant defenses, prevented retinal ganglion cell losses without significant intraocular pressure changes.

In a rat model of estrogen deficiency induced by ovariectomy the use of ALA increased bone mineral density (BMD) and decreased inflammatory markers such as TNF- $\alpha$ and IL-6. Besides these effects, the use of ALA also decreased the levels of osteopontin, a protein related to bone resorption [113]. In a model of low BMD induced by high-fat diet, which is a potent inducer of oxidative stress, the ALA supplementation resulted in an increase of the levels of expression of genes related to antioxidant enzymes, BMD, and biomarkers of bone formation, such as osteocalcin, and a down regulation of genes related to bone resorption activity, like osteoprotegerin, in femur biopsy. These studies indicated a possible action of ALA upon maintenance of bone balance.

\section{Clinical use of ALA in diabetes}

DM comprehends a group of genetically and clinically heterogeneous metabolic disorders that are characterized by hyperglycemia which results from a defective insulin secretion and/or activity [114]. The World Health Organization (WHO), estimated that by 2025 there will be 300 million people with DM in the world. DM carries a great risk of morbidity and mortality due to the microvascular and macrovascular complications that can lead to a lower quality of life and life expectancy [115]. Currently, these complications can be postponed by achieving adequate glycemic control, as demonstrated by the Diabetes Control and Complications Trial, the Epidemiology of Diabetes Interventions and Complications and UKPDS [116-118]. However in routine clinical practice good glycemic control is very difficult to be achieved $[119,120]$. The aforementioned diabetes-related complications lead to a significant burden to the individual and to the society as a whole $[121,122]$.

The mechanisms underlying the development of DM related- chronic complications either micro or macrovascular are associated to glycemic control [90,116-118]. However, many other factors may contribute or have a direct relationship with these complications, such as oxidative stress [123], markers of insulin resistance [124], markers of low-grade inflammation [125], dyslipidemia [126], hypertension [126,127] and obesity [127]. Indeed, DM-related complications may be considered multifactorial as DM itself [114]. In this context, oxidative stress- related hyperglycemia is considered to be more and more important in the development of DM as well in the development of its related complications [85,102]. This duet, oxidative stress- related hyperglycemia may induce modifications in signaling pathways responsible for several 
intracellular processes [102]. Some of these processes are related to inhibition of insulin signaling pathway resulting in insulin resistance [128], reduced insulin gene expression and consequently reduced insulin secretion by beta cells [129]. Moreover, currently there is compelling evidence linking this duet to epigenetic modifications resulting in activation of genetic transcription or repression, silencing the genetic transcription as recently described [45].

In this study it was shown an increasing expression of the subunit p65 of NfKB which resulted in increased transcription of vascular cell adhesion.molecule-1 (VCAM-1) and monocyte chemo attractant molecule-1 (MCP-1) in human aortic endothelial cells under hyperglycemia medium [45]. MCP-1 and VCAM are both related to hyperglycemia-induced arterial pathology. Moreover, this reaction persisted after a long period of normoglycemia establishing the concept of metabolic memory at molecular level.

Recently it was demonstrated also a downregulation of LASY in diabetic animals [18]. In this study either treatment with medium with high glucose or TNF- $\alpha$ resulted in reduction of LASY mRNA [18]. Moreover, a knockout of LAISY showed an intracellular decrease in GSH, superoxide dismutase (SOD) and catalase and an increase in superoxide anion resulting in activation of $\mathrm{NfKB}$, Adding ALA in the cellular medium an up-regulation of LAISY expression was observed [18].

Another important factor in the pathogenesis of diabetesrelated complications is the formation of advanced glycation end-products (AGEs) which are derived from intracellular glucose auto-oxidation and non-enzymatic reactions between glucose and intracellular and extracellular proteins [130-133]. AGEs by different mechanisms may damage target cells located in retina, endothelium and glomeruli [131]. AGEs/receptor interactions (AGE/RAGE) may result in altered functions of intra and extracellular proteins, induction of oxidative stress and modifications of matrix proteins resulting in modifications of its functional properties [132]. AGE may also activate PKC which is a signal transduction pathway for regulating many vascular functions like blood flow, permeability, basement membrane thickening and the expression of nitric oxide synthase [133].

Considering the pleiotropic actions of ALA or its reduced form, DHLA in many signaling pathways associated with the pathophysiologic process of DM development as well as the development of its above mentioned chronic-related complications, its use as a therapeutic agent sounds promising.

\section{Use of ALA in diabetes treatment}

ALA has been used in 94 patients with T2M in a randomized, double-blind placebo-controlled study which has tested three antioxidants for three months in association with metformin and glimeperide: ALA, $300 \mathrm{mg} /$ daily, ecosapentanoic acid, $180 \mathrm{mg}$ plus docohexaenoic acid, $120 \mathrm{mg} /$ daily [omega 3 fatty acids] and vitamin E $400 \mathrm{mg} /$ daily [134]. Although an improvement in HbA1c, weight and waist have been observed with ALA, omega 3 fatty acids gave the better results concerning weight loss and glycemic control [134].

Another randomized, placebo-controlled study with 38 patients treated with different doses of ALA (ranging from 300 to $1200 \mathrm{mg} /$ daily), for six months, showed a decrease in HbA1c and fasting blood glucose in the group randomized to ALA [135]. However, there was only a statistical significant difference only with the pooled group of ALA. The reduction of HbA1c was ALA dose-dependent. Moreover, markers of oxidative stress such as lipid peroxidation and oxidative damage of DNA did not show any modification. Another randomized, double blind placebocontrolled study involving 102 patients treated with ALA (600 mg/daily), ALA $600 \mathrm{mg} /$ daily plus $800 \mathrm{mg} /$ daily of $\alpha-$ tocopherol daily for four months showed improvement in some lipid fractions and glucose in the ALA group and ALA plus $\alpha$-tocopherol but without statistical significance [136]. Data obtained in clinical studies using ALA in the treatment of diabetes-related complications are summarized in Table 2 .

\section{Use of ALA in diabetes-related chronic complications Use of ALA in diabetic retinopathy}

ALA has been used to evaluate retinal mitochondria biogenesis in rats in a model of reinstitution of good control after six months of poor metabolic control [137]. In animals without ALA supplementation and under poor glycemic control it was observed a dysregulation of retinal mitochondria biogenesis with a decreased expression of citrase synthase (a marker of mitochondria functional integrity), a decreased number of mitochondria and an increased number of acellular capillaries (a marker of diabetic retinopathy). Moreover, in this study the supplementation of ALA in animals soon after induction of DM prevented most of the above-mentioned alterations [137]. In another experimental study, the treatment with ALA in diabetic animals reduced the markers of oxidative stress, NfKB activation and vascular endothelial growth factor in diabetic retina [138].

A randomized, double-blind placebo-controlled study with 235 patients with T2D and 170 patients with type 1 diabetes (T1D) patients using ALA $600 \mathrm{mg} /$ daily for 2 years (96 weeks) did not show any kind of prevention upon the development of diabetic macular edema [139]. However, using ALA (400 mg/daly) in combination with other anti-oxidants (genistein and vitamins) in 32 diabetic patients an improvement in electroretinogram was observed after 30 days of treatment [140]. 
Table 2 Clinical studies with ALA in patients with diabetes

\begin{tabular}{|c|c|c|c|c|c|c|c|}
\hline Author & Study type & ALA/other drugs & Analyzed parameters & Total participants & $\begin{array}{l}\text { Duration of } \\
\text { DM (years) }\end{array}$ & $\begin{array}{l}\text { Follow up } \\
\text { (weeks/ years) }\end{array}$ & Results \\
\hline \multicolumn{8}{|c|}{ Type 2 diabetes treatment } \\
\hline Udupa, AS [134] & $\begin{array}{l}\text { Randomized, double- } \\
\text { blind placebo-controlled }\end{array}$ & $\begin{array}{l}\text { Vitamin E, omega } 3 \\
\text { fatty acids ALA } \\
300 \text { mg All of them } \\
\text { daily/orally }\end{array}$ & Weight, waist glucose & 104 with IR & $5-10$ y & $12 \mathrm{w}$ & $\begin{array}{l}<\mathrm{HbA1C} \text {, weight, waist Better } \\
\text { results with omega-3 followed } \\
\text { by vitamin E and ALA }\end{array}$ \\
\hline Porasuphatana S [135] & $\begin{array}{l}\text { Randomized, placebo- } \\
\text { controlled }\end{array}$ & $\begin{array}{l}\text { ALA } 300 \mathrm{mg}-1200 \\
\mathrm{mg} / \mathrm{d}\end{array}$ & $\mathrm{HbA} 1 \mathrm{c}, \mathrm{FBG}$ & 38 & $2.07 \pm 0.26$ & $24 w$ & $<\mathrm{HbA} 1 \mathrm{c}, \mathrm{FBG}$ \\
\hline De Oliveira AM [136] & $\begin{array}{l}\text { Randomized, double- } \\
\text { blind placebo-controlled }\end{array}$ & $\begin{array}{l}\text { ALA } 600 \mathrm{mg} \text { or } \\
\text { Vitamin E } 800 \mathrm{mg} \text { or } \\
\text { ALA } 600 \mathrm{mg} \text { plus } \\
\text { Vitamin E } 800 \mathrm{mgr}\end{array}$ & $\begin{array}{l}\text { HOMA index, glucose, } \\
\text { lipid profile insulin }\end{array}$ & 102 & & $16 w$ & \\
\hline \multicolumn{8}{|c|}{ Diabetic retinopathy } \\
\hline Haritoglou C [139] & $\begin{array}{l}\text { Randomized ,double-blind } \\
\text { placebo-controlled }\end{array}$ & ALA 600 mg/daily & $\begin{array}{l}\text { Development of } \\
\text { macular edema }\end{array}$ & $\begin{array}{l}232 \text { patients with } \\
\text { type } 2 \text { and } 170 \text { with } \\
\text { T1D }\end{array}$ & & $86 w$ & no effect \\
\hline Nebioso M [140] & $\begin{array}{l}\text { Randomized not } \\
\text { placebo-controlled }\end{array}$ & $\begin{array}{l}\text { ALA } 400 \mathrm{mg} \text { daily } \\
\text { plus vitamins and } \\
\text { genistein }\end{array}$ & ERG & 32 & NA & $4 w$ & Improvement in ERG \\
\hline \multicolumn{8}{|c|}{ Diabetic nephropathy } \\
\hline Borcea V [143] & $\begin{array}{l}\text { Cross-sectional not } \\
\text { placebo-controlled }\end{array}$ & ALA 600 mg/daily/orally & $\begin{array}{l}\text { Lipid ROOH, HbA1c, } \\
\text { urine albumin, a } \\
\text { tocopherol }\end{array}$ & $\begin{array}{l}107 \text { patients [ } 45 \text { with } \\
\text { T1D and } 29 \text { with T2D] }\end{array}$ & $\begin{array}{l}21.7 \pm 11.1 \text { (with } \\
\text { ALA); } 15.3 \pm 10.4 \\
\text { (without ALA) }\end{array}$ & $>12 \mathrm{w}$ & $\begin{array}{l}<\mathrm{ROOH}<\mathrm{ROOH} / \text {, a tocopherol/ } \\
\text { cholesterol The decrease was } \\
\text { independent of HbA1c and } \\
\text { urine albumin level }\end{array}$ \\
\hline Cicek M [144] & $\begin{array}{l}\text { Randomized not } \\
\text { placebo-controlled }\end{array}$ & ALA 600 mg/ /orally & $\begin{array}{l}\text { CIN Plasma creatinine, } \\
\text { Cystation C }\end{array}$ & 79 & NA & $\begin{array}{l}\text { Prior coronary } \\
\text { angiography }\end{array}$ & $\begin{array}{l}\text { No effect in the incidence of CIN, } \\
\text { creatinine, Cystatin C pré /pos } \\
\text { exam }\end{array}$ \\
\hline Chang JW [145] & $\begin{array}{l}\text { Randomized } \\
\text { placebo-controlled }\end{array}$ & ALA 600 mg/orally & $\begin{array}{l}\text { Cholesterol, HbA1c } \\
\text { C-reactive protein, } \\
\text { oxidizedLDL- ADMA }\end{array}$ & $\begin{array}{l}50 \text { patients on } \\
\text { hemodyalisis treatment }\end{array}$ & NA & $12 w$ & Decrease the level of ADMA \\
\hline \multicolumn{8}{|c|}{ Diabetes endothelial dysfunction } \\
\hline Heinisch BB [147] & $\begin{array}{l}\text { Randomized, Controlled, } \\
\text { double- blind placebo } \\
\text { parallel }\end{array}$ & $\begin{array}{l}\text { Daily } 600 \mathrm{mg} \text { of } \\
\text { ALA IV }\end{array}$ & $\begin{array}{l}\text { Endothelial function } \\
\text { endothelium dependent } \\
\text { and independent HbA1c, } \\
\text { lipid profile }\end{array}$ & 30 patients with TD2 & $7 \pm 6$ & $3 w$ & $\begin{array}{l}\text { Improvement in endothelium } \\
\text { dependent function }\end{array}$ \\
\hline \multicolumn{8}{|c|}{ Diabetic cardiovascular autonomic neuropathy } \\
\hline Pop-Busui R [150] & $\begin{array}{l}\text { Prospective, randomized, } \\
\text { double- blind, } \\
\text { placebo- controlled }\end{array}$ & $\begin{array}{l}\text { ALA } 600 \text { mg/twice daily } \\
\text { Nicotinamide } 750 \mathrm{mg} / \\
\text { twice daily Allupurinol } \\
300 \mathrm{mg} / \text { daily All of them } \\
\text { orally }\end{array}$ & $\begin{array}{l}\text { Autonomic tests PET } \\
F_{2} \text { urinary isoprostane } \\
\text { HbA1c }\end{array}$ & $\begin{array}{l}44 \text { patients with T1D } \\
\text { with mild/moderate } \\
\text { cardiovascular } \\
\text { autonomic neuropathy } \\
\text { and retinopathy or } \\
\text { microalbuminuria }\end{array}$ & $27 \pm 12$ & $2 y$ & $\begin{array}{l}\text { No improvement in any analyzed } \\
\text { parameter }\end{array}$ \\
\hline
\end{tabular}


Table 2 Clinical studies with ALA in patients with diabetes (Continued)

\begin{tabular}{|c|c|c|c|c|c|c|c|}
\hline Ziegler D [151] & $\begin{array}{l}\text { Randomized, double- } \\
\text { blind, placebo- controlled }\end{array}$ & $\begin{array}{l}\text { ALA } 800 \text { mg/daily } \\
\text { (orally) }\end{array}$ & $\begin{array}{l}\text { Heart rate variability } \\
\text { HbA1c Autonomic } \\
\text { symptoms }\end{array}$ & 73 patients with T2D & $15.3 \pm 8.3$ & $16 w$ & $\begin{array}{l}\text { Improvement on root mean square } \\
\text { successive difference and power } \\
\text { spectrum in low frequency band } \\
\text { No difference in the prevalence } \\
\text { of symptoms }\end{array}$ \\
\hline \multicolumn{8}{|c|}{ Diabetic polyneuropathy } \\
\hline $\begin{array}{l}\text { ZiegleR D [153] } \\
\text { ALADIN I }\end{array}$ & $\begin{array}{l}\text { Randomized,double- } \\
\text { blind controlled parallel }\end{array}$ & $\begin{array}{l}\text { ALA: } 1200 \text { or } 600 \text { or } \\
100 \mathrm{mg} / \text { daily } \\
\text { (orally) }\end{array}$ & TSS HbA1c & $\begin{array}{l}328 \text { patients with T2D } \\
\text { with symptomatic } \\
\text { peripheral neuropathy }\end{array}$ & $10.4 / 12.3$ & $3 w$ & $\begin{array}{l}\text { Improvement in TSS HbA1c: no } \\
\text { difference }\end{array}$ \\
\hline $\begin{array}{l}\text { Reljanovic M } \\
\text { [154] ALADIN II }\end{array}$ & $\begin{array}{l}\text { Prospective randomized, } \\
\text { double- blind controlled }\end{array}$ & $\begin{array}{l}\text { ALA } 1200 \text { mg or } \\
600 \text { mg orally }\end{array}$ & $\begin{array}{l}\text { Sensory and motor } \\
\text { nerve function }\end{array}$ & $\begin{array}{l}299 \text { patients (T1D and } \\
\text { T2D) with symptomatic } \\
\text { polyneuropathy }\end{array}$ & NA & $2 y$ & $\begin{array}{l}\text { Improvement in electrophysiological } \\
\text { tests HbA1c: no difference }\end{array}$ \\
\hline $\begin{array}{l}\text { Ziegler D.[155] } \\
\text { ALADIN III }\end{array}$ & $\begin{array}{l}\text { Prospective randomized, } \\
\text { double- blind controlled }\end{array}$ & $\begin{array}{l}\text { ALA } 600 \mathrm{mg} / \text { IV } \\
\text { followed by } 1800 \mathrm{mg} \\
\text { of ALA or placebo } \\
\text { orally }\end{array}$ & TSS NIS & $\begin{array}{l}516 \text { patients with T2D } \\
\text { with symptomatic } \\
\text { polyneuropathy }\end{array}$ & 11 & $\begin{array}{l}3 w \text { (IV) } 24 \text { w } \\
\text { (orally) }\end{array}$ & No effect HbA1c:no difference \\
\hline $\begin{array}{l}\text { Ametov As [157] } \\
\text { Sidney I }\end{array}$ & $\begin{array}{l}\text { Randomized, double- } \\
\text { blind, parallel controlled, } \\
\text { mono-center }\end{array}$ & ALA 600 mg IV & TSS & $\begin{array}{l}120 \text { (T1D and T2D) } \\
\text { with DSPN }\end{array}$ & $15.1 \pm 8.8$ & 3 & Improvement \\
\hline $\begin{array}{l}\text { Ziegler D [158] } \\
\text { Sidney II }\end{array}$ & $\begin{array}{l}\text { Randomized, double- } \\
\text { blind, parallel controlled, } \\
\text { multicenter }\end{array}$ & $\begin{array}{l}\text { ALA } 600 \text { to } \\
1800 \mathrm{mg} \text { /orally }\end{array}$ & TSS & $\begin{array}{l}181 \text { (T1D and T2D) } \\
\text { with DSPN }\end{array}$ & 14 & 5 & Improvement \\
\hline $\begin{array}{l}\text { Ziegler D [159] } \\
\text { Nathan I }\end{array}$ & $\begin{array}{l}\text { Randomized, double- } \\
\text { blind, parallel controlled, } \\
\text { multicenter }\end{array}$ & ALA 600 mg/orally & $\begin{array}{l}\text { TSS Composite score } \\
\text { ( NIS-lower limbs plus } \\
7 \text { neurophisiologic } \\
\text { tests (NIS-LL+7) }\end{array}$ & $\begin{array}{l}460 \text { (T1D and T2D) } \\
\text { with DSPN }\end{array}$ & 13.3 & 4 years & $\begin{array}{l}\text { TSS: no improvement NSI-LL+7: } \\
\text { improvement }\end{array}$ \\
\hline Ziegler D [160] & Meta-analysis & ALA 600mg IV & TSS, NIS-LL & 1258 & 132 months & $3 w$ & $\begin{array}{l}\text { Improvement in TSS (papin-prick, } \\
\text { touch-pressure), burning,numbness) } \\
\text { Improvement in NIS-LL }\end{array}$ \\
\hline Mijnhout GS [161] & Meta-analysis & $\begin{array}{l}\text { ALA orally ( } 600 \text { to } \\
1800 \mathrm{mg} \text { daily) ALA IV } \\
\text { (100 to } 1200 \mathrm{mg} / \text { daily) }\end{array}$ & TSS & 653 & NA & 3 to $5 w$ & $\begin{array}{l}\text { Improvement in TSS but greater } \\
\text { than 30\% only in intravenously } \\
\text { treated patients }\end{array}$ \\
\hline
\end{tabular}

ALA, alpha-lipoic acid; w, weeks; y, years; IV, intravenously; HbA1c, glycated hemoglobin; FBG, fasting blood glucose; HOMA index, homeostasis model assessment; ERG, electroretinogram; ROOH, hidroxiperoxides;

CIN, contrast induced nephropathy; ADMA, asymmetric dimethyl-arginine; PET, positron emission tomography; TSS, total symptoms score; NIS, neurophaty impairment score; NIS-LL, neuropathy improvement score of lower limbs; T1D, type 1 diabetes; T2D, type 2 diabetes; IR, insulin resistance; DSPN, distal symmetric sensory-motor polyneuropathy. 


\section{Use of ALA in diabetic nephropathy}

The effects of ALA in the development of diabetic nephropathy was investigated mainly in animal studies. In diabetic animal strepzotocin (STZ)-induced DM and apolipoprotein deficient fed high fat diet the protective effect of ALA supplementation was evaluated in three different time schedule : pre-STZ, simultaneously and pos-STZ. No statistical difference was noted among the groups concerning hyperglycemia, although an attenuation of hyperglycemia was observed in the group pre-STZ. Analyzing the pooled group it was found a reduction in IL-6, urine albumin, urine isoprostane and an increase in erythrocyte GSH in the group under ALA supplementation. The decreased gene expression of superoxide dismutase in diabetic animals was normalized with ALA. Two other animal studies showed interesting data $[141,142]$. One study showed that LASY-deficient animals present reduction in antioxidant defense. Moreover, in this study it was also found an overproduction of superoxide in the proximal tubular cells which could be an important event for accelerating the development of diabetic nephropathy [141]. Another study showed opposite action of ALA in animals with STZ-induced DM. In diabetic animals ALA decreased urinary albumin and markers of oxidative stress, but in non-diabetic animals pro-oxidant effects were observed with an increase in urinary albumin, creatinine and markers of oxidative stress [142]. This effect may be at least partially explained by the high dose used in the experiment.

So far, the few human studies which have been done had different objectives [143-145]. One cross-sectional not placebo controlled study using $600 \mathrm{mg} /$ daily of ALA for more than three months in 107 patients with T2D and T1D showed a reduction of lipid hydroxiperoxides. Moreover this reduction was independent of the level of HbA1c and urine albumin [143].

The protective effect of ALA on the development of contrast-induced nephropathy (CIN) was evaluated in 68 patients with DM undergoing coronary angiography. The patients received $600 \mathrm{mg}$ of TA prior to the procedure or no treatment (control group). The two groups had the same incidence of CIN, $8 \%$, without difference in the plasma levels of creatinine, cystatin $\mathrm{C}$ pre/pos procedure [144]. The effect of ALA upon asymmetric dimetihylarginine (ADMA) which is an inhibitor of nitric oxid synthase, was investigated in a randomized, control study for 12 week in 50 diabetic patients undergoing hemodyalisis. ALA, $600 \mathrm{mg} /$ daily decreased the levels of ADMA without difference in the other analyzed parameters [145]. An open and non-randomized exploratory study, investigated the effect of $600 \mathrm{mg} /$ daily of ALA for 72 weeks on urinary albumin excretion and plasma levels of trombomodulin in patients with T1D and T2D. A decrease in the level of trombomodulin and no changes in the urinary albumin were observed in the treatment group [146].

\section{Use of ALA in endothelial dysfunction}

A randomized, controlled, double blind, parallel study with 30 patients with T2D evaluated glycemic control and endothelial responses to intravenous acetylcholine (endothelium dependent) and nitrate (endothelium independent) in order to evaluate the forearm blood flow before and after the use of $600 \mathrm{mg}$ of ALA intravenously for three weeks [147]. A decrease in HbA1c, total cholesterol and triglycerides levels were observed in both groups. However only the patients ALA treated showed an improvement in the endothelium dependent vasodilation. ALA or placebo did not influence endothelium independent vasodilation [147].

\section{Use of ALA in diabetic wound healing}

An experimental study in vitro and in vivo has demonstrated a possible benefit of topical application of ALA alone or in combination with other anti-oxidant agents for diabetic wound healing [148]. In this study the expression of RAGE was attenuated in skin wound in diabetic animals when ALA was used in combination with other anti-oxidants agents for one week. Moreover, the use of ALA in combination with other anti-oxidants agents accelerated the skin wound healing with increased expression of vascular endothelial growth factor (VEGF) in the wound area.

\section{Use of ALA in diabetic cardiovascular neuropathy}

Cardiovascular autonomic neuropathy was evaluated in two human studies. One, randomized, double blind, placebo controlled multicenter study (DEKAN) was conducted in patients with T2D with cardiovascular autonomic neuropathy (CAN) using $800 \mathrm{mg}$ of ALA daily for 16 weeks [149]. Autonomic symptoms and heart rate variability were evaluated before and after the intervention. The intervention with ALA resulted in improvement of some parameters of heart rate variability analysis: root mean square successive difference and power spectrum in low frequency band. No difference was observed in overall symptoms. Another study, a prospective, randomized, double blind, placebo controlled study was performed in 44 patients with T1D presenting any diabetes-related chronic complication (mild non-proliferative retinopathy or microalbuminuria and the presence of cardiac autonomic neuropathy (CAN) defined by an alteration of positron emission tomography (PET) with normal autonomic reflex testing [150]. Patients were submitted to triple anti-oxidant therapy with the objective to target different pathways of oxidative stress damage: inhibition of xantina-oxidase by allopurinol $300 \mathrm{mg} /$ daily, inhibition of oxidative stress by ALA, $600 \mathrm{mg} /$ twice daily and inhibition 
of poly (ADP-ribose) [11]. In this study no improvement was found in all parameters of autonomic function analysis as well as in urinary levels of isoprostanes, a marker of oxidative stress. Meanwhile a detrimental effect in some regions of left ventricle was observed in PET analysis [150].

\section{Use of ALA in diabetic neuropathy}

So far, the majority of clinical studies using ALA therapeutically were conducted in order to evaluate its action on diabetic neuropathy. The earlier studies were performed between 1980/1993. In general these studies were uncontrolled, double/single blind or open label, including few patients, had short duration and used a wide range dose either orally or intravenous [11]. The main benefit of ALA was an improvement of symptoms and in distal motor never latencies. It is beyond the scope of this review to analyze each of these studies but they did not have a definite conclusion about the effects of ALA upon diabetic neuropathy. However they have given key information about how to perform other clinical trials better designed to in order to evaluate this topic. It is important to emphasize that at this time the lack of standardization of definition as well as standard criteria for diagnosing diabetic neuropathy are unsolved problems due to different worldwide consensus in the subject. These consensuses have established scores like Neuropathy Symptoms Score (NSS), Total Symptoms Score (TSS), and Neuropathy Impairment Score (NIS) $[139,151,152]$ which addressed the intensity and frequency of the most important symptoms of diabetic neuropathy such as pain, burning, numbness and paresthesias. The above-mentioned scores facilitated a normatization of the outcomes in these clinical trials after the 1990's [153-159]. The first of these studies was the ALADIN (Alpha Lipoic Acid in Diabetic Neuropathy) which was designed to evaluate the efficacy and safety of intravenous ALA during three weeks in three different doses, $1200 \mathrm{mg}, 600 \mathrm{mg}$ and $100 \mathrm{mg}$ in comparison to placebo in 328 patients with T2D with symptomatic distal symmetric diabetic polineuropathy (DSPN) [153]. In this study an improvement in TSS was noted in the group using $600 \mathrm{mg}$ vs placebo establishing the safety and efficacy of this dose in comparison to the $1200 \mathrm{mg}$ dose. Moreover, at the dose of $1200 \mathrm{mg}$ a higher rate of adverse events were observed mainly in the gastrointestinal tract. No difference in HbA1c was observed at the end of the study which included 260 patients. This study was followed by ALADIN II which was a long-term trial (24 months) that addressed also electrophysiological tests and Neuropathy Disability Score (NDS) using the same doses of ALA but orally in 299 patients with T2D. In this study only 65 patients could be included in the final analysis because the variability in the electrophysiological tests biased the final results [154]. Although some improvement in sensory nerve function was noted the excessive number of patients excluded should be considered when interpreting these results. The ALADIN III Study has combined $600 \mathrm{mg}$ of ALA intravenously for three weeks followed either by $600 \mathrm{mg}$ of ALA three times daily or placebo for six months (24 weeks) [155]. No improvement in TSS and NIS were observed at the end of the study, although some analyzed parameters such as NIS and TSS presented positive results in short period of ALA intravenously administration (tree weeks). Moreover, a high rate of dropout was noted (about 25\%). Recently three randomized, double blind, controlled parallel studies were concluded addressing the efficacy and safety of ALA in diabetic patients with DSPN with TSS or NIS as primary outcome. The majority of the included patients had T2D (up to 70\%) [156]. The SYDNEY Trial, a monocenter, short-term study used ALA intravenously during five days a week for three weeks and showed improvement in TSS [157]. The SIDNEY 2 Trial was a multicenter study which used doses of ALA ranging from 600 to $1800 \mathrm{mg}$ daily and also showed an improvement in TSS [158]. Finally, it is important to mention the NATHAN 1 Trial (Neurological Assessment of Thioctic Acid in Diabetic Neuropathy), a multicenter study which used $600 \mathrm{mg}$ of ALA daily for four years with NIS-Lower Limb + seven neurophysiologic tests as primary outcome. In this study after a four-year treatment with ALA in mild-to-moderate DSPN did not influence the primary composite end point but resulted in a significant clinical improvement and prevention of progression of neuropathic impairments. As the primary composite end point did not deteriorate in placebo-treated subjects, secondary prevention of its progression by ALA according to the trial design was not feasible [159]. All these latter studies concluded that the usual dose of $600 \mathrm{mg}$ has efficacy and safety and adverse events, mainly in the gastrointestinal tract, that were dose dependent. Moreover, with one exception (sural latency), all these studies did observe improvement in electrophysiological tests.

Two recent meta-analysis evaluate the use of ALA in diabetic neuropathy $[160,161]$. One, included 1,258 diabetic patients treated with $600 \mathrm{mg}$ of ALA, intravenously for three weeks, concluded that individualized TTS such as pain, numbness and burning decreased significantly with ALA in comparison to placebo. Considering the components of NIS-LL an improvement was noted in pin-prick, touch pressure and ankle reflexes [160]. This meta-analysis also pointed out some relevant aspects for conducting future trials to evaluate the benefits of ALA on diabetic neuropathy as follows: homogeneity of the studied patients; duration of the trial; end-points with less variability and finally considering the slowing progression of diabetic neuropathy the end point must have to exclude the latter and address improvement. The other meta-analysis included 653 diabetic patients 
treated with different doses of ALA oral (two studies) or intravenously (two studies) for three (3 studies) to 5 weeks (one study) concluded that TSS decreased significantly but only in the intravenously study the TSS decrease more than $30 \%$ which was considered to be clinically significant [161]. Recently, a non-randomized, openlabel and prospective study has shown an improvement in pain and eletroneurographic parameters, mainly in sensory nerve conduction, in 50 patients with diabetes and symmetric sensorimotor polyneuropathy treated with a new oral formulation combining ALA $400 \mathrm{mg} /$ daily and superoxide dismutase 140 IU/daily for four months [162].

Recently, a randomized, open label, parallel study showed no benefit of adding methylcobalamine(750 ug) and $A L A(100 \mathrm{mg})$ to pregabalin $(75 \mathrm{mg})$ for 12 weeks in parameters of nerve function and pain evaluation [163]. Another prospective, observational study showed that after 21 months patients using pregabalin had better improvement in symptoms of diabetic neuropathy in comparison to patients using either carbamazepine and $A L A[164]$.

\section{Adverse events}

Adverse events related to the administration of ALA were described mainly in clinical trials [153,158,159] but generally without difference when compared with placebo. The majority of these adverse events were dose-dependent and in the gastrointestinal tract (nausea, vomiting, dyspepsia and abdominal pain). However other events were also described like pruritus, bronchitis and skin ulceration. Recently it was described a case of insulin autoimmune syndrome probably associated with the use of ALA as a nutritional supplement [165].

\section{Conclusions}

ALA a natural anti-oxidant is a cofactor of mitochondrial enzymes of oxidative metabolism like pyruvate dehydrogenase which link glycolysis to citric acid cycle, and $\alpha$-keto-glutarate dehydrogenase. ALA and its reduced form DHLA have many biological functions in different intracellular systems resulting in a wide range of actions such as antioxidant protection, chelation of metal ions, regeneration of other antioxidant agents such as vitamin C, E and glutathione. Moreover, ALA/DHLA can also act in multiple signaling transduction pathways, like insulin, nuclear factor kappa B (NFkB), nitric oxide synthesis and cellular apoptosis. Also, ALA/DHLA can modulate directly or indirectly the expression of protein kinase $C$ and AMPK that are both key enzymes in many downstream systems. All the aforementioned described actions confer some properties to ALA/DHLA that are not just related to its reactive oxygen and nitrogen species scavenger but also to glucose disposal, inflammation, tumorigenesis, endothelial function, appetite regulation and cognitive function. To date, the majority of these actions have been addressed mainly in experimental studies which used a wide range dose of ALA in vitro as well as in vivo. We can also consider that for instance, the used dose was greater than the physiological dose reached with the usual clinically used oral dose of ALA. It is also to be mentioned that in most of these studies it was not well defined which type of ALA has been used. Finally, the translation of all these pooled experimental data to human studies is a subject for further research.

\section{Perspectives}

Currently, there are compelling evidences linking oxidative damage to the majority of chronic diseases with increasing prevalence worldwide such as obesity, DM, CVD and AD. Considering the pleiotropic action of ALA upon different pathways associated with the above mentioned diseases, its use as a potential therapeutical agent seems promising. So far, although in a limited number, the majority of clinical studies, performed in randomized double-blind and placebo-controlled ways, have been done in diabetic patients with DSPN. Future clinical studies, also randomized double-blind and placebo-controlled with adequate sample calculation, homogeneity of the studied patients, longer duration and a minimal variability in the established outcomes are needed in order to asses the benefit of ALA upon other diabetes-related chronic complications. Considering the latter statement it will be an important issue to define the use of ALA as primary or secondary therapeutic intervention. Also, the same aforementioned type of studies with the same criteria must be addressed in other clinical conditions such as obesity, CVD and AD. Another important question to be answered by these clinical studies is when we are going to start its use according to the natural evolution of each disease in order to reach a benefit. We need also more experimental studies to evaluate and define if the pro-oxidant action of ALA is dose-dependent. These studies may also give us more information about the use of lipoic acid synthase as a molecular target for increasing the mitochondrial levels of ALA. Another point to be addressed in these studies is the possibility that hyperglycemia can affect different pathways resulting in a toxicity which could be independent of oxidative stress as recently discussed [166]. The role of endoplasmic reticulum stress has been pointed out as an important mechanism leading to diabetes-related complications which is independent of oxidative stress.

Finally, although our review had the objective to extended our clinical and biological knowledge about ALA we still need more information about this multifunctional compound to spread its use in routine clinical practice. 


\section{Abbreviations}

ALA: Alpha-lipoic acid; TA: Thioctic acid; DHLA: Dihydrolipoic acid; GSH: Glutathione peroxidase; NFkB: Nuclear factor kappa B; DM: Diabetes mellitus; acetyl-CoA: Acetyl coenzyme A; Nrf2: Nuclear factor erythroid 2-related factor; IR: Insulin receptor; IRS1: Insulin receptor substrate 1; PI3K: Phosphatidylinositide 3-kinase; AKT: Protein kinase B; IKB: Inhibitors of nuclear factor kappa B; AMPK: 5' adenosine monophosphate-activated protein kinase; LKB-1: Liver kinase B1; CaMKK: Ca/calmodulin dependent protein kinase; PGC-1-alpha: Protein kinase-peroxisome proliferator-activated receptor-gamma coactivator-1alpha; CVD: Cardiovascular disease; TNF-a: Tumor necrosis factor alpha; IL-6: Interleukine 6; MCP-1: Monocyte chemokine protein-1; NAFLD: Non-alcoholic fatty liver disease; NASH: Non-alcoholic steatohepatites; BMS: Burning mouth syndrome; TLR4: Toll-like receptor 4; FMD: Flow-mediated vasodilation; STZ: Streptozotocin; BMD: Bone mineral density; T2D: Type 2 diabetes; WHO: World Health Organization; VCAM-1: Vascular cell adhesion.molecule-1; AGEs: Advanced glycation end-products; AGE/RAGE: AGEs/receptor interactions; LASY: Lipoic acid synthase; T1D: Type 1 diabetes; CIN: Contrast-induced nephropathy; ADMA: Asymmetric dimetihylarginine; VEGF: Vascular endothelial growth factor; CAN: Cardiac autonomic neuropathy; PET: Positron emission tomography; NSS: Neuropathy symptoms score; TSS: Total symptoms score; NIS: Neuropathy impairment score; ALADIN: Alpha lipoic acid in diabetic neuropathy; DSPN: Symptomatic distal symetric diabetic polineuropathy; NDS: Neuropathy disability score; NATHAN: Neurological assessment of thioctic acid in diabetic neuropathy.

\section{Competing interest}

The authors declare that they have no competing interests.

\section{Authors' contributions}

MBG and CAN contributed equally analyzing the data and writing the manuscript. Both authors read and approved the final manuscript.

\section{Author details}

'Department of Internal Medicine, Diabetes Unit, State University Hospital of Rio de Janeiro, Avenida 28 de Setembro, 77, $3^{\circ}$ andar CEP 20.551-030, Rio de Janeiro, Brazil. ${ }^{2}$ Department of Internal Medicine, Bauru's Diabetics Association, 17012-433, Bauru, São Paulo, Brazil.

Received: 5 May 2014 Accepted: 11 July 2014

Published: 28 July 2014

\section{References}

1. Golbidi S, Badran M, Laher I: Diabetes and alpha lipoic Acid. Front Pharmacol 2011, 2:69.

2. Reed L: From lipoic acid to multi-enzyme complexes. Protein Sci 1998, 7(1):220-224.

3. Shay KP, Moreau RF, Smith EJ, Smith AR, Hagen TM: Alpha-lipoic acid as a dietary supplement: molecular mechanisms and therapeutic potential. Biochim Biophys Acta 2009, 1790(10):1149-1160.

4. Snell EE, Strong FM, Peterson WH: Growth factor for bacteria.VI Fractionation and properties of an accessory factor for lactic acid bacteria. Bichem J 1937, 31:1789-1799.

5. Reed LJ, De Busk BG, Gunsalus IC, Hornberger CS: Cristalline alpha-lipoic acid: a catalytic agent associated with pyruvate dehydrogenase. Science 1951, 114:93-94.

6. Bock E, Schneeweiss J: Ein Beitrag zur Therapie der neuropathia diabetic Munchner Med Wochenschrift 1959, 43:1911-1912.

7. Wray DW, Nishyyama SK, Harris RA, Zhao J, McDaniel J, Fjeldstad AS, Witman MA, Ives SJ, Barrett-O'Keefe Z, Richardson RS: Acute reversal of endothelial dysfunction in the elderly following antioxidant consumption. Hypertension 2012, 59:818-824.

8. McNeilly AM, Davison GW, Murphy MH, Nadeem N, Trinick T, Duly E, Novials A, McEneny J: Effect of a-lipoic acid and exercise training on cardiovascular disease risk in obesity with impaired glucose tolerance. Lipids Health Dis 2011, 10:217

9. Zhang WJ, Bird KE, MCMillen TS, LeBoeuf RC, Hagen TM, Frei B: Dietary alphalipoic acid supplementation inhibits atherosclerotic lesion development in apolipoprotein E-deficient and apolipoprotein E/low-density lipoprotein receptor-deficient mice. Circulation 2008, 117(3):421-428.
10. Ying Z, Kherada N, Farrar B, Kampfrath T, Chung Y, Simonetti O, Deiuliis J, Desikan R, Khan B, Villamena F, Sun Q, Parthasarathy S, Rajagopalan S: Lipoic acid effects on established atherosclerosis. Life Sci 2010, 86(3-4):95-102.

11. Ziegler D, Reljanovic M, Mehnert H, Gries FA: a Lipoic acid in the treatment of diabetic polyneuropathy in Germany: current evidence from clinical trials. Exp Clin Endocrinol Diabetes 1999, 107:421-430.

12. Packer $L$, Kraemer $K$, Rimbach $G$ : Molecular aspects of lipoic acid in the prevention of diabetes complications. Nutrition 2001, 17:888-895.

13. Vasdev S, Ford CA, Parai S, Longerich L, Gadag V: Dietary alpha-lipoic acid supplementation lowers blood pressure in spontaneously hypertensive rats. J Hypertens 2000, 18(5):567-573.

14. Moreira PI, Harris PLR, Zhu X, Santos MS, Oliveira CR, Smith MA, Perry G: Lipoic acidi and n-acetyl cysteine decrease mitochondrial-related oxidative stress in Alzheimer disease patient fibroblasts. J Alzheimers Dis 2007 12:195-206

15. Lott IT, Doran E, Nguyen VQ, Tournay A, Head E, Gillen DL: Down syndrome and dementia: a randomized, controlled trial of antioxidant supplementation. Am J Med Genet A 2011, 155A:1939-1948.

16. Al Abdan M: Alfa-lipoic acid controls tumor growth and modulates hepatic redox state in Ehrlich-ascites-carcinoma-bearing mice. Scientific World Journal 2012, 2012:509838.

17. Szelag M, Mikulski D, Molski M: Quantum-chemical investigation of the structure and the antioxidant properties of a-lipoic acid and its metabolites. J Mol Model 2012, 18:2907-2916.

18. Padmalayam I, Hasham S, Saxena U, Pillarisetti S: Lipoic acid synthase (LASY): a novel role in inflammation, mitochondrial function, and insulin resistance. Diabetes 2009, 58:600-608.

19. MCLain AL, Cormier PJ, Kinter M, Szweda LI: Glutathionylation of a-ketoglutarate dehydrogenase: the chemical nature and relative susceptibility of the cofactor lipoic acid to modification. Free Radic Biol Med 2013, 61C:161-169.

20. Hassan $\mathrm{BH}$, Cronan JE: Protein-protein interactions in assembly of lipoic acid on the 2-oxoacid dehydrogenases of aerobic metabolism. J Biol Chem 2011, 286:8263-8276.

21. Moini H, Tirosh O, Park YC, Cho KJ, Packer L: R-alpha-lipoic acid action on cell redox status, the insulin receptor, and glucose uptake in 3T3-L1 adipocytes. Arch Biochem Biophys 2002, 397(2):384-391.

22. A-Vadlapudi AD, Vadlapatla RK, Mitra AK: Sodium dependent multivitamin transporter (SMVT): a potential target for drug delivery. Curr Drug Targets 2012, 13:994-1003.

23. Scott BC, Aruoma OI, Evans PJ, O'Neill C, Van der Vliet A, Cross CE, Tritschler $\mathrm{H}$, Halliwell B: Lipoic and dihydrolipoic acids as antioxidants. A critical evaluation. Free Radic Res 1994, 20(2):119-133.

24. Packer $\mathrm{L}$, Witt EH, Tritschler HJ: Alpha-lipoic acid as a biological antioxidant. Free Rad Biol Med 1995, 19(2):227-250.

25. Trujillo M, Radi R: Peroxynitrite reaction with the reduced and the oxidized forms of lipoic acid: new insights into the reaction of peroxynitrite with thiols. Arch of Biochem and Biophys 2002, 397(1):91-98.

26. Vriesman MF, Haenen GR, Westerveld GJ, Paquay JB, Voss HP, Bast A: A method for measuring nitric oxide radical scavenging activity. Scavenging properties of sulfur-containing compounds. Pharm World SCi 1997, 19(6):283-286.

27. Suzuki YJ, Tsuchiya M, Packer L: Thioctic acid and dihydrolipoic acid are novel antioxidants which interact with reactive oxygen species. Free Radic Res Commun 1991, 15(5):255-263.

28. Suzuki YJ, Tsuchiya M, Packer L: Antioxidant activities of dihydrolipoic acid and its structural homologues. Free Radic Res Commun 1993, 18(2):115-122.

29. Devasagayam TP, Di Mascio P, Kaiser S, Sies H: Singlet oxygen induced single-strand breaks in plasmid pBR322 DNA: the enhancing effect of thiols. Biochim Biophys Acta 1991, 1088(3):409-412

30. Kagan VE, Shvedova A, Serbinova E, Khan S, Swanson C, Powell R, Packer L: Dihydrolipoic acid-a universal antioxidant both in the membrane and in the aqueous phase. Reduction of peroxyl, ascorbyl and chromanoxyl radicals. Biochem Pharmacol 1992, 44(8):1637-1649.

31. Haenen GR, Bast A: Scavenging of hypochlorous acid by lipoic acid. Biochem Pharmacol 1991, 42(11):2244-2246.

32. Newsholme P, Rebelato E, Abdulkader F, Krause M, Carpinelli A, Curi R: Reactive oxygen and nitrogen species generation, antioxidant defenses, and $\beta$-cell function: a critical role for amino acids. J Endocrinol 2012, 214(1):11-20. 
33. Koriyama $Y$, Nakayama $Y$, Matsugo S, Kato S: Protective effect of lipoic acid against oxidative stress is mediated by Keap1/Nrf2-dependent heme oxygenase-1 induction in the RGC-5 cellline. Brain Res 2013, 1499:145-157.

34. Wilking M, Ndiaye $M$, Mukhtar $H$, Ahmad N: Circadian rythms connections to oxidative stress: implications for human health. Antioxid Redox Signal 2013, 19:192-208.

35. Dicter N, Madar Z, Tirosh O: Alpha-lipoic acid inhibits glycogen synthesis in rat soleus muscle via its oxidative activity and the uncoupling of mitochondria. J Nutr 2002, 132(10):3001-3006.

36. Rouchette L, Ghibu S, Richard C, Zeller M, Cottin Y, Vergely C: Direct and indirect antioxidant properties of a -lipoic acid. Mol Nutr Food Res 2013, 57:114-125

37. Moini $H$, Packer $L$, Saris N-E: Antioxidant and prooxidant activities of a-lipoic acid and dihydrolipoic acid. Toxicol Appl Pharmacol 2002, 182:84-90.

38. Zhang DD, Lo S-C, Cross JV, Templeton DJ, Hannink M: keap1 is a redox-regulated substrate adaptor protein for a Cul3-dependent ubiquitin ligase complex. Mol Cell Biol 2004, 24:10941-10953.

39. Dinkova-kostova AT, Talalay P: Direct and indirect antioxidant properties of inducers of cytoprotective proteins. Mol Nutr Food Res 2008, 52:S128-S138.

40. Frizzell N, Baynes JW: Chelation therapy: overlooked in the treatment and prevention of diabetes complications? Future Med Chem 2013, 5(10):1075-1078

41. Ou P, Tritscheler HJ, Wolff SP: Thioctic (lipoic acid): a therapeutical metal-chelating antioxidant? Biochem Pharmacol 1995, 50:123-126.

42. Bast A, Haenen GR: Lipoic acid: a multifunctional antioxidant. Biofactors 2003, 17(1-4):207-213.

43. Smith AR, Shenvi SV, Widlansky M, Suh JH, Hagen TM: Lipoic acid as a potential therapy for chronic diseases associated with oxidative stress. Curr Med Chem 2004, 11(9):1135-1146.

44. Yaworsky K, Somwar R, Ramlal T, Tritschler HJ, Klip A: Engagement of the insulin-sensitive pathway in the stimulation of glucose transport by alpha-lipoic acid in 3T3-L1 adipocytes. Diabetologia 2000, 43(3):294-303.

45. Estrada DE, Ewart HS, Tsakiridis T, Volchuk A, Ramlal T, Tritschler H, Klip A: Stimulation of glucose uptake by the natural coenzyme alpha-lipoic acid/thioctic acid: participation of elements of the insulin signaling pathway. Diabetes 1996, 45(12):1798-1804.

46. Henriksen EJ, Jacob S, Streeper RS, Fogt DL, Hokama JY, Tritschler HJ: Stimulation by alpha-lipoic acid of glucose transport activity in skeletal muscle of lean and obese Zucker rats. Life Sci 1997, 61(8):805-812.

47. Yamamoto $Y$, Gaynor RB: Therapeutical potential of inhibition of the NFkb pathway in the treatment of inflammation and cancer. J Clin Invest 2001, 107(2):135-142.

48. El-Osta A, Brasacchio D, Yao D, Pocai A, Jones PL, Roeder RG, Cooper ME, Brownlee M: Transient high glucose causes persistent epigenetic changes and altered gene expression during subsequent normoglycemia. J Exp Med 2008, 205(10):2409-2417

49. Bierhaus A, Chevion S, Chevion M, Hofmann M, Quehenberger P, Illmer T, Luther T, Berentshtein E, Tritschler H, Müller M, Wahl P, Ziegler R, Nawroth PP: Advanced glycation end product-induced activation of NF-kappaB is suppressed by alpha-lipoic acid in cultured endothelial cells. Diabetes 1997, 46(9):1481-1490.

50. Ying Z, Kampfrath T, Sun Q, Parthasarathy S, Rajagopalan S: Evidence that a-lipoic acid inhibits NF-KB activation independent of its antioxidant function. Inflamm Res 2011, 60(3):219-225.

51. Zembron-Lacny A, Gajeswski M, Naczac M, Dziewiecka H, Siatkkowski I: Physical activity and alpha-lipoic acid modulate inflammatory response through changes in thiol redox status. J Physiolo 2013, 69:397-404.

52. Sola S, Mir MQ, Cheema FA, Khan-Merchant N, Menon RG, Parthasarathy S, Khan BV: Irbesartan and lipoic acid improve endothelial function and reduce markers of inflammation in the metabolic syndrome: results of the Irbesartan and Lipoic Acid in Endothelial Dysfunction (ISLAND) study. Circulation 2005, 111(3):343-348.

53. Steinberg GR, Kemp BE: AMPK in health and disease. Physiol Rev 2009 , 89(3):1025-1078

54. Zhou G, Myers R, Li Y, Chen Y, Shen X, Fenyk-Melody J, Wu M, Ventre J, Doebber T, Fujii N, Musi N, Hirshman MF, Goodyear L, Moller DE: Role of AMP-activated protein kinase in mechanism of metformin action. J Clin Invest 2001, 108(8):1167-1174.
55. Shen QW, Zhu MJ, Tong J, Ren J, Du M: Ca2+/calmodulin-dependent protein kinase kinase is involved in AMP-activated protein kinase activation by alpha-lipoic acid in C2C12 myotubes. Am J Physiol Cell Physiol 2007, 293(4):C1395-C1403.

56. Wang Y, Li X, Guo Y, Chan L, Guan X: Alpha-Lipoic acid increases energy expenditure by enhancing adenosine monophosphate-activated protein kinase-peroxisome proliferator-activated receptor-gamma coactivator-1alpha signaling in the skeletal muscle of aged mice. Metabolism 2010, 59(7):967-976.

57. Targonsky ED, Dai F, Koshkin V, Karaman GT, Gyulkhandanyan AV, Zhang Y, Chan CB, Wheeler MB: Alpha-lipoic acid regulates AMP-activated protein kinase and inhibits insulin secretion from beta cells. Diabetologia 2006, 49(7):1587-1598.

58. Koh G, Yang EJ, Kim MK, Lee SA, Lee DH: Alpha-lipoic acid treatment reverses 2-deoxy-D-ribose-induced oxidative damage and suppression of insulin expression in pancreatic $\beta$-cells. Biol Pharm Bull 2013. [Epub ahead of print]. doi:10.12478/bpb.13-00292.

59. Ramamurthy S, Ronnet G: AMP-activated protein kinase (AMPK) and energy sensing in the brain. Exp Neurobiol 2012, 21(2):52-60.

60. Blazquez C, Geelen MJ, Velasco G, Guzmán M: The AMP activated protein kinase prevents ceramide synthesis de novo and astrocytes. FEBS Lett 2001, 489(2-3):149-153.

61. Nakatsu Y, Kotake Y, Hino A, Ohta S: Activation of AMO-activated protein kinase by tributyltin induces neuronal cell death. Toxicol Appl Pharmacol 2008, 230(3):358-363.

62. Kim MS, Park JY, Namkoong C, Jang PG, Ryu JW, Song HS, Yun JY, Namgoong IS, Ha J, Park IS, Lee IK, Viollet B, Youn JH, Lee HK, Lee KU: Anti-obesity effects of alpha-lipoic acid mediated by suppression of hypothalamic AMP-activated protein kinase. Nat Med 2004, 10(7):727-733.

63. Seo EY, Ha AW, Kim WK: a lipoic acid reduced weight gain and improved lipid profile in rats fed with high fat diet. Nutr Res Pract 2012, 6:195-200.

64. Tomassoni D, Amenta F, Amantini C, Farfariello V, Di Cesare ML, Nwankwo IE, Marini C, Tayebati SK: Brain activity of thioctic acid enantiomers: in vitro and in vivo studies in an animal model of cerebrovascular injury. Int J Mol Sci 2013, 14(3):4580-4595.

65. Cho KJ, Moon HE, Moini H, Packer L, Yoon DY, Chung AS: Alpha-lipoic acid inhibits adipocyte differentiation by regulating pro-adipogenic transcription factors via mitogen-activated protein kinase pathways. J Biol Chem 2003, 278(37):34823-34833.

66. Wang Y, Dong W, Ding X, Wang F, Wang Y, Chen X, Yu L, Li X, Zhang A, Peng $Y$ : Protective effect of a-lipoic acid on islet cells co-cultured with 3T3L1 adipocytes. Exp Ther Med 2012, 4(3):469-474.

67. Tian YF, He CT, Chen YT, Hsieh PS: Lipoic acid suppresses portal endotoxemia-induced steatohepatitis and pancreatic inflammation in rats. World J Gastroenterol 2013, 19(18):2761-2771.

68. Ong SL, Vohra H, Zhang Y, Sutton M, Whitworth JA: The effect of alphalipoic acid on mitochondrial superoxide and glucocorticoid-induced hypertension. Oxid Med Cell Longev 2013, 2013:517045. doi:10.1155/2013/ 517045. Epub 2013 Feb 26.

69. Li CJ, LV L, Li H, Yu D: Cardiac fibrosis and dysfunctionin experimental diabetic cardiomyopathy are amelioreted by alpha-lipoic acid. Cardiovasc Diabetol 2012, 11:142. doi:10.1186/1475-2840-11-142.

70. Deng C, Sun Z, Tong G, Yi W, Ma L, Zhao B, Cheng L, Zhang J, Cao F, Yi D: a-Lipoic acid reduces infarct size and preserves cardiac function in rat myocardial ischemia/reperfusion injury through activation of PI3K/Akt/ Nrf2 pathway. PLoS One 2013, 8(3):e58371.

71. Yi X, Nickeleit $V$, James LR, Maeda N: a-Lipoic acid protects diabetic apolipoprotein E-deficient mice from nephropathy. J Diabetes Complications 2011, 25(3):193-201

72. Inman DM, Lambert WS, Calkins DJ, Horner PJ: a-Lipoic acid antioxidant treatment limits glaucoma-related retinal ganglion cell death and dysfunction. PLOS One 2013, 8(6):e65389.

73. Jha MK, Jeon S, Suk K: Pyruvate Dehydrogenase Kinases in the nervous system: their principal functions in Neuronal-glial metabolic interaction and Neuro-metabolic disorders. Curr Neuropharmacol 2012, 10:393-403.

74. Carvalho C, Cardoso S, Correia SC, Santos RX, Santos MS, Baldeiras I, Oliveira CR, Moreira PI: Metabolic alterations induced by sucrose intake and Alzheimer's disease promote similar brain mitochondrial abnormalities. Diabetes 2012, 61(5):1234-1242.

75. Maher PA, Schubert DR: Metabolic links between diabetes and Alzheimer's disease. Expert Rev Neurother 2009, 9:617-630. 
76. Piau A, Nourhashémi F, Hein C, Caillaud C, Vellas B: Progress in the development of new drugs in Alzheimer's disease. J Nutr Health Aging 2011, 15(1):45-57.

77. Sancheti H, Akopian G, Yin F, Brinton RD, Walsh JP, Cadenas E: Age-dependent modulation of synaptic plasticity and insulin mimetic effect of lipoic acid on a mouse model of Alzheimer's disease. PLoS One 2013, 8:e69830.

78. Gupta A, Bisht B, Dey CS: Peripheral insulin-sensitizer drug metformin ameliorates neuronal insulin resistance and Alzheimer's-like changes. Neuropharmacology 2011, 60(6):910-920

79. Maczurek A, Hager K, Kenklies M, Sharman M, Martins R, Engel J, Carlson DA Münch G: Lipoic acid as an anti-inflammatory and neuroprotective treatment for Alzheimer's disease. Adv Drug Deliv Rev 2008, 60:1463-1470.

80. Hager K, Kenklies M, McAfoose J, Engel J, Münch G: Alpha-lipoic acid as a new treatment option for Alzheimer's disease-a 48 months follow-up analysis. J Neural Transm Supp/ 2007, 72:189-193.

81. Cho JY, Um HS, Kang EB, Cho HH, Kim CH, Cho JS, Hwang DY: The combination of exercise training and alpha-lipoic acid treatment has therapeutic effects on the pathogenic phenotypes of Alzheimer's disease in NSE/APPsw-transgenic mice. Int J Mol Med 2010, 25(3):337-346.

82. Prieto-Hontoria PL, Pérez-Matute P, Fernández-Galilea M, Alfredo Martínez J, Moreno-Aliaga MJ: Effects of lipoic acid on AMPK and adiponectin in adipose tissue of low- and high-fat-fed rats. Eur J Nutr 2013, 52(2):779-787.

83. Deiuliis JA, Kampfrath T, Ying Z, Maiseyeu A, Rajagopalan S: Lipoic acid attenuates innate immune infiltration and activation in the visceral adipose tissue of obese insulin resistant mice. Lipids 2011, 46:1021-1032.

84. Lamb RE, Goldstein BJ: Modulating an oxidative-inflmmatory cascade: potential new treatment strategy for improving glucose metabolism, insulin resistance, and vascular function. Int J Clin Pract 2008, 62(7):1087-1095.

85. Xiao C, Giacca A, Lewis GF: Short-term oral a-lipoic acid does not prevent lipid-induced dysregulation of glucose homeostasis in obese and overweight nondiabetic men. Am J Physiol Endocrinol Metab 2011, 301:E736-E741.

86. Zhang Y, Han P, Wu N, He B, Lu Y, Li S, Liu Y, Zhao S, Liu L, Li Y: Amelioration of lipid abnormalities by a-lipoic acid through antioxidative and anti-inflammatory effects. Obesity (Silver Spring) 2011, 19(8):1647-1653.

87. Koh EH, Lee WJ, Lee SA, Kim EH, Cho EH, Jeong E, Kim DW, Kim MS, Park JY, Park KG, Lee HJ, Lee IK, Lim S, Jang HC, Lee KH, Lee KU: Effects of alpha-lipoic acid on body weight in obese subjects. Am J Med 2011, 124:85.e1-85.e8.

88. Ratliff JC, Palmese LB, Reutenauer EL, Tek C: An open-label pilot trial of alpha-lipoic acid for weight loss in patients with schizophrenia without diabetes. Clin Schizophr Relat Psychoses 2013, 7:1-13. Jose516@ hotmail.com.

89. Lean MEJ: Sibutramine: a review of clinical efficacy. In J Obes 1997 21:30S-36S.

90. Lazo M, Clark JM: The epidemiology of nonalcoolic faty liver disease: a global perspective. Semin Liver Dis 2008, 28:339-350.

91. Dixon JB, Bhathal PS, O'Brien PE: Nonalcoholic fatty liver disease: predictors of nonalcoholic steatohepatitis and liver fibrosis in the severely obese. Gastroenterology 2001, 121(1):91-100.

92. Valdecantos MP, Pérez-Matute P, González-Muniesa P, Prieto-Hontoria PL, Moreno-Aliaga MJ, Martínez JA: Lipoic acid administration prevents nonalcoholic steatosis linked to long-term high-fat feeding by modulating mitochondrial function. J Nutr Biochem 2012, 23(12):1676-1684.

93. Jung TS, Kim SK, Shin HJ, Jeon BT, Hahm JR, Roh GS: a-lipoic acid prevents non-alcoholic fatty liver disease in OLETF rats. Liver Int 2012, 32:1565-1573

94. Valdecantos MP, Pérez-Matute P, González-Muniesa P, Prieto-Hontoria PL, Moreno-Aliaga MJ, Martínez JA: Lipoic acid improves mitochondrial function in nonalcoholic steatosis through the stimulation of sirtuin 1 and sirtuin 3. Obesity 2012, 20(10):1974-1983.

95. Chen WL, Kang CH, Wang SG, Lee HM: a-Lipoic acid regulates lipid metabolism through induction of sirtuin 1 (SIRT1) and activation of AMP-activated protein kinase. Diabetologia 2012, 55(6):1824-1835.

96. Chong ZZ, Shang YC, Wang S, Maiesse K: SIRT1: new avenues of discovery for disorders of oxidative stress. Expert Opin Ther Targets 2012, 16:167-178.

97. Gurvits GE, Tan A: Burning mouth syndrome. World J Gastroenterol 2013, 7:665-672.

98. Cavalcanti DR, da Silveira FR: Alpha lipoic acid in burning mouth syndrome-a randomized double-blind placebo-controlled trial. J Oral Pathol Med 2009, 38:254-261
99. Femiano F, Lanza A, Buonaiuto C, Gombos F, Nunziata M, Cuccurullo L, Cirillo N: Burning mouth syndrome and burning mouth in hypothyroidism: proposal for a diagnostic and therapeutic protocol. Oral Surg Oral Med Oral Pathol Oral Radiol Endod 2008, 105:e22-e27.

100. Femiano F: Burning mouth syndrome (BMS): an open trial of comparative efficacy of alpha-lipoic acid (thioctic acid) with other therapies. Minerva Stomatol 2002, 51:405-409.

101. Hu G, Jousilhati P, Qiao Q, Katoh S: Sex differences in cardiovascular and total mortality among diabetic and non-diabetic individuals with or without history of myocardial infarction. Diabetologia 2005, 48:856-861.

102. Brownlee M: Biochemistry and molecular cell biology of diabetic complications. Nature 2001, 414:813-820.

103. Kris-Etherton PM, Lichtenstein AH, Howard BV, Steinberg D, Witztum JL, Nutrition Committee of the American Heart Association Council on Nutrition, Physical Activity, and Metabolism: Antioxidant vitamin supplements and cardiovascular disease. Circulation 2004, 110(5):637-641.

104. McMackin CJ, Widlansky ME, Hamburg NM, Huang AL, Weller S, Holbrook M, Gokce N, Hagen TM, Keaney JF Jr, Vita JA: Effect of combined treatment with alpha-Lipoic acid and acetyl-L-carnitine on vascular function and blood pressure in patients with coronary artery disease. J Clin Hypertens (Greenwich) 2007, 9(4):249-255.

105. Durand M, Mach N: Alpha lipoic acid and its antioxidant against cancer and diseases of central sensitization. Nutr Hosp 2013, 28:1031-1038.

106. Michikoshi H, Nakamura T, Sakai K, Suzuki Y, Adachi E, Matsugo S, Matsumoto K: a-Lipoic acid-induced inhibition of proliferation and met phosphorylation in human non-small cell lung cancer cells. Cancer Lett 2013, 335(2):472-478.

107. Feuerecker B, Pirsig S, Seidl C, Aichler M, Feuchtinger A, Bruchelt G, Senekowitsch-Schmidtke R: Lipoic acid inhibits cell proliferation of tumor cells in vitro and in vivo. Cancer Biol Ther 2012, 13(14):1425-1435.

108. Kim Jl, Cho SR, Lee CM, Park ES, Kim KN, Kim HC, Lee HY: Induction of ER stress-mediated apoptosis by a-Lipoic Acid in A549 cell lines. Korean J Thorac Cardiovasc Surg 2012, 45(1):1-10.

109. Mantovani G, Macciò A, Madeddu C, Mura L, Gramignano G, Lusso MR, Murgia V, Camboni P, Ferreli L: The impact of different antioxidant agents alone or in combination on reactive oxygen species, antioxidant enzymes and cytokines in a series of advanced cancer patients at different sites: correlation with disease progression. Free Radic Res 2003, 37(2):213-223

110. Guais A, Baronzio G, Sanders E, Campion F, Mainini C, Fiorentini G, Montagnani F, Behzadi M, Schwartz L, Abolhassani M: Adding a combination of hydroxycitrate and lipoic acid (METABLOC ${ }^{\text {TM }}$ ) to chemotherapy improves effectiveness against tumor development: experimental results and case report. Invest New Drugs 2012, 30:200-211.

111. Diesel B, Kulhanek-Heinze S, Höltje M, Brandt B, Höltje HD, Vollmar AM, Kiemer AK: Alpha-lipoic acid as a directly binding activator of the insulin receptor: protection from hepatocyte apoptosis. Biochemistry 2007, 46(8):2146-2155.

112. Polat B, Halici Z, Cadirci E, Albayrak A, Karakus E, Bayir Y, Bilen H, Sahin A, Yuksel TN: The effect of alpha-lipoic acid in ovariectomy and inflammation-mediated osteoporosis on the skeletal status of rat bone. Eur J Pharmacol 2013. doi:S0014-2999 (13)00555-4. 10.1016

113. Xiao Y, Cui J, Shi Y, Le G: Lipoic acid increases the expression of genes involved in bone formation in mice fed a high-fat diet. Nutr Res 2011, 31(4):309-317.

114. Skyler J, Oddo C: Diabetes trends in the USA. Diabetes Metab Res Ver 2002, 18:S21-S26.

115. Wild S, Roglic G, Green A, Sicree R, King H: Global prevalences of diabetes, estimates for the year 2000 and projections for 2030. Diabetes Care 2004, 27:1047-1053.

116. The Diabetes Control and Complications Trial Study Research Group: The effect of intensive treatment of diabetes on the development and progression of long-term complications in insulin-dependent diabetes mellitus. N Eng J Med 1993, 329:977-986.

117. The Diabetes Control and Complications Trial/Epidemiology of Diabetes Interventions and Complications (DCCT/EDIC) Study Research Group: Intensive diabetes treatment and cardiovascular disease in patients with diabetes type 1. N Engl J Med 2005, 353:2643-2653.

118. Stratton IM, Adler Al, Neil AW, Matthews DR, Manley SE, Cull CA, Hadden D, Turner RC, Holman RR, on behalf of the UK Prospective Diabetes Study Group: Association of glycaemia with macrovascular and microvascular complications of type 2 diabetes (UKPDS 35): prospective observational study. BMJ 2000, 321:405-412. 
119. Gomes MB, de Mattos Matheus AS, Calliari LE, Luescher JL, Manna TD, Savoldelli RD, Cobas RA, Coelho WS, Tschiedel B, Ramos AJ, Fonseca RM, Araujo NB, Almeida HG, Melo NH, Jezini DL, Negrato CA: Economic status and clinical care in young type 1 diabetes patients: a nationwide multicenter study in Brazil. Acta Diabetol 2013, 50(5):743-752. Epub 2012 Jun 12

120. Gomes MB, Giannella-Neto D, Faria M, Tambascia MA, Fonseca RM, Rea RR, Macedo G, Modesto Filho J, Schmid H, Bittencourt AV, Cavalcanti S, Rassi N, Pedrosa H, Atala Dib S: Prevalence of type 2 diabetic patients within the targets of care guidelines in daily clinical practice: a multicenter study in Brazil. Rev Diabet Stud 2006, 3:82-87.

121. American Diabetes Association: Economic costs of diabetes in the US in 2007. Diabetes Care 2008, 31:596-615

122. Cobas RA, Ferraz MB, Matheus ASM, Tannus LRM, Negrato CA, Araújo LA Dib SA, Gomes MB, Brazilian Type 1 Diabetes Study Group: The cost of type 1 diabetes: a nationwide multicentre study in Brazil. Bull World Health Organ 2013, 91:434-440.

123. Ceriello A, Sudhesh K, Piconi L, Esposito K, Giugliano D: Simultaneous control of hyperglycemia and oxidative stress normalizes endothelial function in type 1 diabetes. Diabetes Care 2007, 30(3):649-654.

124. Orchard TJ, Olson JC, Erbey JR, Williams K, Forrest KY, Smithline Kinder L, Ellis D, Becker DJ: Insulin resistance-related factors, but not glycemia, predict coronary artery disease in type 1 diabetes. Diabetes Care 2003, 26(5):1374-1379.

125. Gomes MB, Cobas RA, Nunes E, Castro-Faria-Neto HC, da Matta MF, Neves R Plasma PAF-acetylhydrolase activity, inflammatory markers and susceptibility of LDL to in vitro oxidation in patients with type 1 diabetes mellitus. Diabetes Res Clin Pract 2009, 85:61-68.

126. Grundy SM, Benjamin IJ, Burke GL, Chait A, Eckel RH, Howard BV, Mitch W, Smith SC Jr, Sowers JR: Diabetes and cardiovascular disease: a statement for healthcare professionals from the American Heart Association. Circulation 1999, 100(10):1134-1146.

127. van Vliet M, Van der Heyden JC, Diamant M, Von Rosenstiel IA, Schindhelm RK, Aanstoot HJ, Veeze HJ: Overweight is highly prevalent in children with type 1 diabetes and associates with cardiometabolic Risk. J Pediatr 2010, 156(6):923-929.

128. Evans JL, Goldfine ID, Maddux BA, Grodsky GM: Are oxidative stress-activated signaling pathways mediators of insulin resistance and beta-cell dysfunction? Diabetes 2003, 52(1):1-8.

129. Chang YC, Chuang LM: The role of oxidative stress in the pathogenesis of type 2 diabetes: from molecular mechanism to clinical implication. Am J Transl Res 2010, 2(3):316-331.

130. Singh R, Barden A, Mori T, Beilin L: Advanced glycation end- products: a review. Diabetologia 2001, 44(2):129-146.

131. Giugliano D, Ceriello A, Paolisso G: Oxidative stress and diabetic vascular complications. Diabetes Care 1996, 19(3):257-267.

132. Ruderman NB, Williamson JR, Brownlee M: Glucose and diabetic vascular disease. FASEB J 1992, 6(11):2905-2914.

133. Di Mario U, Pugliese G: 15th Golgi lecture: from hyperglycaemia to the dysregulation of vascular remodelling in diabetes. Diabetologia 2001, 44(6):674-692

134. Udupa AS, Nahar PS, Shah SH, Kshirsagar MJ, Ghongane BB: Study of comparative effects of antioxidants on insulin sensitivity in type 2 diabetes mellitus. J Clin Diagn Res 2012, 6(9):1469-1473.

135. Porasuphatana S, Suddee S, Nartnampong A, Konsil J, Harnwong B, Santaweesuk A: Glycemic and oxidative status of patients with type 2 diabetes mellitus following oral administration of alpha- lipoic acid: a randomized double-blinded placebo-controlled study. Asia Pac J Clin Nutr 2012, 21(1):12-21.

136. de Oliveira AM, Rondó PH, Luzia LA, D'Abronzo FH, Illison VK: The effects of lipoic acid and a-tocopherol supplementation on the lipid profile and insulin sensitivity of patients with type 2 diabetes mellitus: a randomized, double-blind, placebo-controlled trial. Diabetes Res Clin Pract 2011, 92(2):253-260.

137. Santos JM, Kowluru RA: Role of mitochondria biogenesis in the metabolic memory associated with the continued progression of diabetic retinopathy and its regulation by lipoic acid. Invest Ophthalmol Vis Sci 2011, 52(12):8791-8798.

138. Lin J, Bierhaus A, Bugert P, Dietrich N, Feng Y, Vom Hagen F, Nawroth $P$, Brownlee M, Hammes HP: Effect of R-(+)-alpha-lipoic acid on experimental diabetic retinopathy. Diabetologia 2006, 49(5):1089-1096.
139. Haritoglou C, Gerss J, Hammes HP, Kampik A, Ulbig MW, RETIPON Study Group: Alpha-lipoic acid for the prevention of diabetic macular edema. Ophthalmologica 2011, 226(3):127-137.

140. Nebbioso M, Federici M, Rusciano D, Evangelista M, Pescosolido N: Oxidative stress in preretinopathic diabetes subjects and antioxidants. Diabetes Technol Ther 2012, 14(3):257-263.

141. Yi X, Xu L, Hiller S, Kim HS, Nickeleit V, James LR, Maeda N: Reduced expression of lipoic acid synthase accelerates diabetic nephropathy. J Am Soc Nephrol 2012, 23(1):103-111.

142. Bhatti F, Mankhey RW, Asico L, Quinn MT, Welch WJ, Maric C: Mechanisms of antioxidant and pro-oxidant effects of alpha-lipoic acid in the diabetic and nondiabetic kidney. Kidney Int 2005, 67(4):1371-1380.

143. Borcea V, Nourooz-Zadeh J, Wolff SP, Klevesath M, Hofmann M, Urich H, Wahl P, Ziegler R, Tritschler H, Halliwell B, Nawroth PP: alpha- Lipoic acid decreases oxidative stress even in diabetic patients with poor glycemic control and albuminuria. Free Radic Biol Med 1999, 26(11-12):1495-1500.

144. Cicek M, Yıldırır A, Okyay K, Yazici AC, Aydinalp A, Kanyilmaz S, Muderrisoglu $\mathrm{H}$ : Use of alpha-lipoic acid in prevention of contrast- induced nephropathy in diabetic patients. Ren Fail 2013, 35(5):748-753.

145. Chang JW, Lee EK, Kim TH, Min WK, Chun S, Lee KU, Kim SB, Park JS: Effects of alpha-lipoic acid on the plasma levels of asymmetric dimethylarginine in diabetic end-stage renal disease patients on hemodialysis: a pilot study. Am J Nephrol 2007, 27(1):70-74.

146. Morcos M, Borcea V, Isermann B, Gehrke S, Ehret T, Henkels M, Schiekofer S, Hofmann M, Amiral J, Tritschler H, Ziegler R, Wahl P, Nawroth PP: Effect of alpha-lipoic acid on the progression of endothelial cell damage and albuminuria in patients with diabetes mellitus: an exploratory study. Diabetes Res Clin Pract 2001, 52(3):175-183.

147. Heinisch BB, Francesconi M, Mittermayer F, Schaller G, Gouya G, Wolzt M, Pleiner J: Alpha-lipoic acid improves vascular endothelial function in patients with type 2 diabetes: a placebo-controlled randomized trial. Eur J Clin Invest 2010, 40(2):148-154

148. Chen SA, Chen HM, Yao YD, Hung CF, Tu CS, Liang YJ: Topical treatment with anti-oxidants and Au nanoparticles promote healing of diabetic wound through receptor for advance glycation end-products. Eur J Pharm Sci 2012, 47(5):875-883.

149. Ziegler D, Schatz H, Conrad F, Gries FA, Ulrich H, Reichel G: Effects of treatment with the antioxidant alpha-lipoic acid on cardiac autonomic neuropathy in NIDDM patients. A 4-month randomized controlled multicenter trial (DEKAN Study). Deutsche Kardiale Autonome Neuropathie. Diabetes Care 1997, 20(3):369-373.

150. Pop-Busui R, Stevens MJ, Raffel DM, White EA, Mehta M, Plunkett CD, Brown $M B$, Feldman EL: Effects of triple antioxidant therapy on measures of cardiovascular autonomic neuropathy and on myocardial blood flow in type 1 diabetes: a randomised controlled trial. Diabetologia 2013, 56(8):1835-1844.

151. Ziegler D: Diagnosis and mangement of diabetic peripheral neuropathy Diabet Med 1996, 13(suppl 1):S34-S38.

152. Dyck PJ, Davies JL, Litchy WJ, O'Brien PC: Longitudinal assessment of diabetic polyneuropathy using a composite score in the Rochester Diabetic Neuropathy Study cohort. Neurology 1997, 49(1):229-239.

153. Ziegler D, Hanefeld M, Ruhnau KJ, Meissner HP, Lobisch M, Schütte K, Gries FA: Treatment of symptomatic diabetic peripheral neuropathy with the anti-oxidant alpha-lipoic acid. A 3-week multicentre randomized controlled trial (ALADIN Study). Diabetologia 1995, 38(12):1425-1433.

154. Reljanovic M, Reichel G, Rett K, Lobisch M, Schuette K, Möller W, Tritschler $\mathrm{HJ}$, Mehnert H: Treatment of diabetic polyneuropathy with the antioxidant thioctic acid (alpha-lipoic acid): a two year multicenter randomized double-blind placebo-controlled trial (ALADIN II). Alpha Lipoic Acid in Diabetic Neuropathy. Free Radic Res 1999, 31(3):171-179.

155. Ziegler D, Hanefeld M, Ruhnau KJ, Hasche H, Lobisch M, Schütte $K$, Kerum G, Malessa R: Treatment of symptomatic diabetic polyneuropathy with the antioxidant alpha-lipoic acid: a 7-month multicenter randomized controlled trial (ALADIN III Study). ALADIN III Study Group. Alpha-Lipoic Acid in Diabetic Neuropathy. Diabetes Care 1999, 22(8):1296-1301.

156. Ruhnau KJ, Meissner HP, Finn JR, Reljanovic M, Lobisch M, Schütte K, Nehrdich D, Tritschler HJ, Mehnert H, Ziegler D: Effects of 3-week oral treatment with the antioxidant thioctic acid (alpha-lipoic acid) in symptomatic diabetic polyneuropathy. Diabet Med 1999, 16(12):1040-1043. 
157. Ametov AS, Barinov A, Dyck PJ, Hermann R, Kozlova N, Litchy WJ, Low PA, Nehrdich D, Novosadova M, O'Brien PC, Reljanovic M, Samigullin R, Schuette K, Strokov I, Tritschler HJ, Wessel K, Yakhno N, Ziegler D, SYDNEY Trial Study Group: The sensory symptoms of diabetic polyneuropathy are improved with alpha-lipoic acid: the SYDNEY trial. Diabetes Care 2003, 26(3):770-776.

158. Ziegler D, Ametov A, Barinov A, Dyck PJ, Gurieva I, Low PA, Munzel U, Yakhno N, Raz I, Novosadova M, Maus J, Samigullin R: Oral treatment with alpha-lipoic acid improves symptomatic diabetic polyneuropathy: the SYDNEY 2 trial. Diabetes Care 2006, 29(11):2365-2370.

159. Ziegler D, Low PA, Litchy WJ, Boulton AJ, Vinik Al, Freeman R, Samigullin R, Tritschler H, Munzel U, Maus J, Schütte K, Dyck PJ: Efficacy and safety of antioxidant treatment with a-lipoic acid over 4 years in diabetic polyneuropathy: the NATHAN 1 trial. Diabetes Care 2011, 34(9):2054-2060.

160. Ziegler D, Nowak H, Kempler P, Vargha P, Low PA: Treatment of symptomatic diabetic polyneuropathy with the antioxidant alpha-lipoic acid: a meta-analysis. Diabet Med 2004, 21(2):114-121.

161. Mijnhout GS, Kollen BJ, Alkhalaf A, Kleefstra N, Bilo HJ: Alpha lipoic acid for symptomatic neuropathy in patients with diabetes: A meta-analysis of randomized controlled trials. Int J Endocrinol 2012, 2012:456279. doi:10.1155/2012/456279.

162. Bertolloto F, Massome A: Combination of alpha lipoic acid and superoxide dismutase leads to physiological and symptomatic improvements in diabetic neuropathy. Drugs 2012, 12:29-34.

163. Vasudevan D, Naik MM, Mukaddam Ql: Efficacy and safety of methylcobalamin, alpha lipoic acid and pregabalin combination versus pregabalin monotherapy in improving pain and nerve conduction velocity in type 2 diabetes associated impaired peripheral neuropathic condition. Results of a pilot study. Ann Indian Acad Neurol 2014, 17:19-24. doi:10.4103/0972-2327.128535.

164. Patel N, Mishra V, Patel P, Dikshot RK: A study of the use of carbamazepine, pregabalin and alpha lipoic acid in patients of diabetic neuropathy. J Diabetes Metab Disord 2014, 13:62.

165. Bresciani E, Busi A, Bazzigaluppi E, Balestere G: Insulin autoimmune syndrome induced by a lipoic acid in a Caucasian woman: case report. Diabetes Care 2011, 34:e146.

166. Mooradian AD, Haas MJ: Glucose-induced endoplasmic reticulum stress is independent of oxidative stress: a mechanistic explanation for the failure of antioxidant therapy in diabetes. Free Radic Biol Med 2011, 50:1140-1143.

doi:10.1186/1758-5996-6-80

Cite this article as: Gomes and Negrato: Alpha-lipoic acid as a pleiotropic compound with potential therapeutic use in diabetes and other chronic diseases. Diabetology \& Metabolic Syndrome 2014 6:80.

\section{Submit your next manuscript to BioMed Central and take full advantage of:}

- Convenient online submission

- Thorough peer review

- No space constraints or color figure charges

- Immediate publication on acceptance

- Inclusion in PubMed, CAS, Scopus and Google Scholar

- Research which is freely available for redistribution 